\title{
Quantifying the effects of clear-cutting and strip-cutting on nitrate dynamics in a forested watershed using triple oxygen isotopes as tracers
}

\author{
U. Tsunogai ${ }^{1}$, D. D. Komatsu ${ }^{1, *}$, T. Ohyama ${ }^{1}$, A. Suzuki ${ }^{2}$, F. Nakagawa ${ }^{2, * *}$, I. Noguchi $^{3}$, K. Takagi $^{4}$, M. Nomura $^{4}$, \\ K. Fukuzawa ${ }^{4}$, and H. Shibata ${ }^{4}$ \\ ${ }^{1}$ Graduate School of Environmental Studies, Nagoya University, Furo-cho, Chikusa-ku, Nagoya 464-8601, Japan \\ ${ }^{2}$ Earth and Planetary System Science, Faculty of Science, Hokkaido University, N10 W8, Kita-ku, Sapporo 060-0810, Japan \\ ${ }^{3}$ Institute of Environmental Sciences, Environmental and Geological Research Department, Hokkaido Research Organization, \\ N19 W12, Kita-ku, Sapporo 060-0819, Japan \\ ${ }^{4}$ Field Science Center for Northern Biosphere, Hokkaido University, N9 W9, Kita-ku, Sapporo 060-0809, Japan \\ * present address: School of Marine Science and Technology, Tokai University, 3-20-1, Orido, Shimizu-ku, Shizuoka-shi, \\ Shizuoka 424-8610, Japan \\ *** present address: Graduate School of Environmental Studies, Nagoya University, Furo-cho, Chikusa-ku, Nagoya 464-8601, \\ Japan
}

Correspondence to: U. Tsunogai (urumu@nagoya-u.jp)

Received: 7 April 2014 - Published in Biogeosciences Discuss.: 21 May 2014

Revised: 31 August 2014 - Accepted: 1 September 2014 - Published: 7 October 2014

\begin{abstract}
Temporal variations in the stable isotopic compositions of nitrate dissolved in stream water eluted from a cool-temperate forested watershed ( $8 \mathrm{ha}$ ) were measured to quantify the biogeochemical effects of clear-cutting of trees and subsequent strip-cutting of the understory vegetation, dwarf bamboo (Sasa senanensis), with special emphasis on changes in the fate of atmospheric nitrate that had been deposited onto the watershed based on $\Delta^{17} \mathrm{O}$ values of nitrate. A significant increase in stream nitrate concentration to $15 \mu \mathrm{mol} \mathrm{L}^{-1}$ in spring of 2004 was correlated with a significant increase in the $\Delta{ }^{17} \mathrm{O}$ values of nitrate. Additionally, the high $\Delta^{17} \mathrm{O}$ values of $+14.3 \%$ o suggest that the direct drainage of atmospheric nitrate accounted for more than $50 \%$ of total nitrate exported from the forested watershed peaking in spring. Similar increases in both concentrations and $\Delta^{17} \mathrm{O}$ values were also found in spring of 2005 . Conversely, low $\Delta^{17} \mathrm{O}$ values less than $+1.5 \%$ were observed in other seasons, regardless of increases in stream nitrate concentration, indicating that the majority of nitrate exported from the forested watershed during seasons other than spring was remineralized nitrate: those retained in the forested ecosystem as either organic $\mathrm{N}$ or ammonium and then been converted to nitrate via microbial nitrification.
\end{abstract}

When compared with the values prior to strip-cutting, the annual export of atmospheric nitrate and remineralized nitrate increased more than 16-fold and fourfold, respectively, in 2004, and more than 13-fold and fivefold, respectively, in 2005. The understory vegetation (Sasa) was particularly important to enhancing biological consumption of atmospheric nitrate.

\section{Introduction}

\subsection{Effects of clear-cutting and strip-cutting on nitrate in stream water}

Investigation of nitrate in stream water eluted from a forested watershed is important to understanding nitrogen cycles within the watershed. In addition, the nitrate concentration in stream water is important to primary production downstream. Increased nitrate in stream water can degrade stream habitats. However, nitrate concentrations in stream water eluted from forested watersheds are determined through a complicated interplay of several processes including (1) deposition of atmospheric nitrate $\left(\mathrm{NO}_{3 \mathrm{~atm}}^{-}\right)$, (2) production of remineralized 
nitrate $\left(\mathrm{NO}_{3}^{-}\right.$re $)$through nitrification, (3) uptake by plants or microbes, and (4) reduction through denitrification. As a result, interpretation of the processes regulating nitrate concentration in stream water is not always straightforward.

Clear-cutting of plants in forested watersheds often leads to nitrate increasing to levels as high as $1000 \mu \mathrm{mol} \mathrm{L}^{-1}$ in stream water eluted from the watersheds (Likens et al., 1970; Swank et al., 2001), as well as acidification (Likens et al., 1970; Swank et al., 2001; Vitousek and Melillo, 1979). Enhancement of the production of fresh remineralized nitrate within soils due to disturbances and/or hindrance of the uptake of such remineralized nitrate in soils might play a large role in increases in nitrate in streams. Moreover, previous studies of forested catchments have offered considerable insight into the link between atmospheric nitrate deposition and nitrate discharge to streams (Grennfelt and Hultberg, 1986; Williams et al., 1996; Tietema et al., 1998; Durka et al., 1994). As a result, disturbances to forested watersheds can also increase direct drainage of atmospheric nitrate in stream water subsequent to deposition by hindering biological uptake processes of atmospheric nitrate within forested watersheds.

Temporal variations in stream and soil solution chemistry, fine root biomass, and soil nitrogen processing in accordance with clear-cutting of trees and subsequent strip-cutting of understory vegetation (mainly Sasa senanensis) were measured in a forested watershed in the Teshio Experimental Forest, Hokkaido University (Fig. 1) in northern Japan (Fukuzawa et al., 2006). In that study, an approximately $50 \%$ decrease in fine root biomass due to understory vegetation cutting was found to induce an increase in the maximum nitrate concentration in stream water from $3 \mu \mathrm{mol} \mathrm{L}-1$ to ca. $15 \mu \mathrm{mol} \mathrm{L}-1$ and that in soil solution from $30 \mu \mathrm{mol} \mathrm{L}^{-1}$ to more than $100 \mu \mathrm{mol} \mathrm{L}^{-1}$. These results implied that nitrogen uptake by the understory vegetation was important to preventing nitrogen leaching after tree-cutting, and that the decline of this nitrogen uptake by removal of understory vegetation led to marked nitrate leaching to stream water (Fukuzawa et al., 2006). However, the importance of atmospheric nitrate as the source of increased nitrate in the stream water has not been evaluated to date. Quantitative evaluation of the source of increased nitrate in stream water subsequent to artificial clear-cutting and strip-cutting will improve our understanding of $\mathrm{N}$ cycling in forested soils prior to artificial alternations, as well as the mechanisms that regulate the direct discharge of $\mathrm{NO}_{3}^{-}$atm deposited onto surface ecosystems (Durka et al., 1994; Ohte et al., 2004; Costa et al., 2011; Nakagawa et al., 2013). Thus, in this study, we conducted further isotope analysis of archived stream water samples to clarify the source of increased nitrate.

\subsection{Triple oxygen isotopic compositions of nitrate}

The natural stable isotopic composition of nitrate has been widely applied in the determination of the sources of nitrate

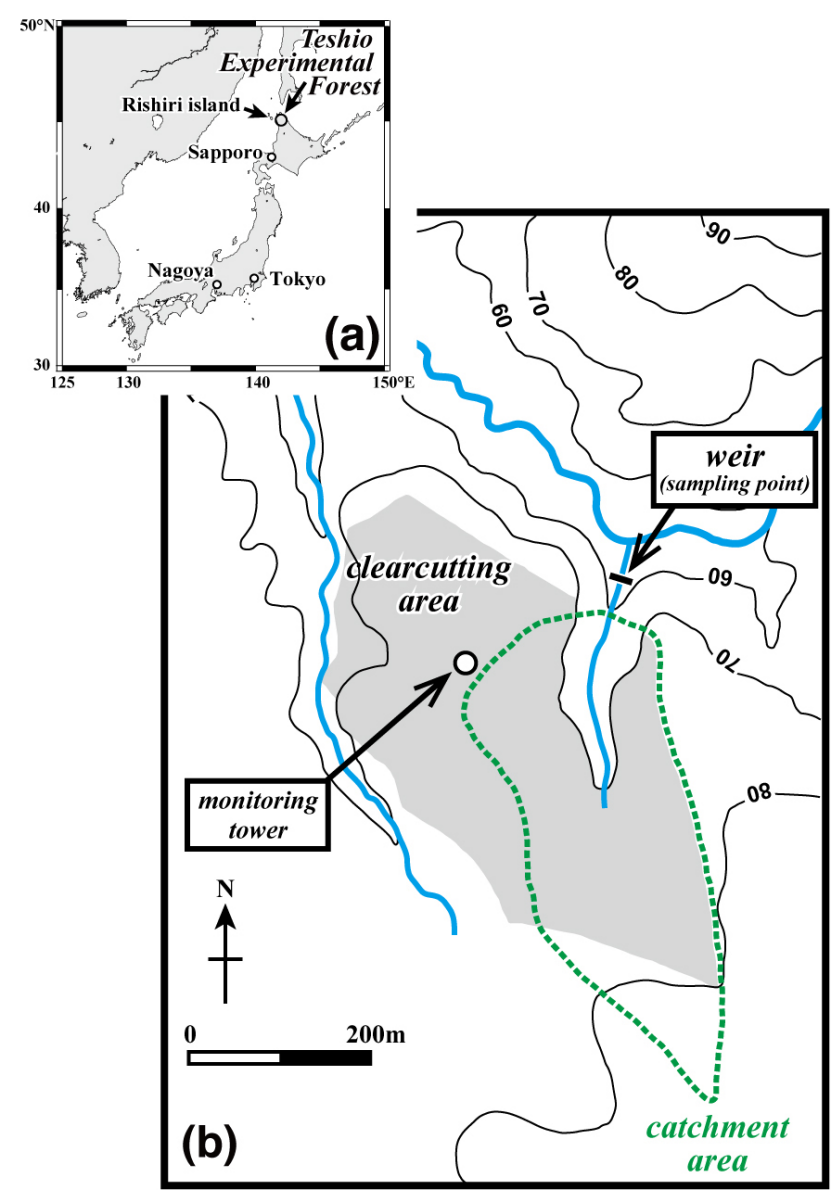

Figure 1. Map showing the location of Teshio Experimental Forest in northern Japan (a), and a contour map showing the water sampling point (weir) in the forest (b), together with both the catchment area shown by a dotted line and the clear-cutting area of the CC-LaG project shown by the hatched region. The white circle denotes the location of the monitoring tower.

in natural freshwater systems (Wada et al., 1975; Durka et al., 1994; Williard et al., 2001; Burns and Kendall, 2002; Campbell et al., 2002; Michalski et al., 2004; Ohte et al., 2004; Hales et al., 2007; Barnes et al., 2008; Burns et al., 2009; Tsunogai et al., 2010; Tobari et al., 2010; Ohte et al., 2010; Barnes and Raymond, 2010; Tsunogai et al., 2011; Nestler et al., 2011; Curtis et al., 2011; Costa et al., 2011; Pellerin et al., 2012; Dejwakh et al., 2012; Yue et al., 2013; Ohte, 2013; Lohse et al., 2013; Thibodeau et al., 2013; Nakagawa et al., 2013). In particular, triple oxygen isotopic compositions of nitrate have been shown to be a conservative tracer of atmospheric nitrate $\left(\mathrm{NO}_{3 \mathrm{~atm}}^{-}\right)$. While remineralized nitrate $\left(\mathrm{NO}_{3 \mathrm{re}}^{-}\right)$, the oxygen atoms of which are derived from either terrestrial $\mathrm{O}_{2}$ or $\mathrm{H}_{2} \mathrm{O}$ through microbial processing (i.e., nitrification), always shows mass-dependent relative relation between ${ }^{17} \mathrm{O} /{ }^{16} \mathrm{O}$ ratios and ${ }^{18} \mathrm{O} /{ }^{16} \mathrm{O}$ ratios; $\mathrm{NO}_{3}^{-}$atm displays an anomalous enrichment in ${ }^{17} \mathrm{O}$ reflecting oxygen 
atom transfers from atmospheric ozone $\left(\mathrm{O}_{3}\right)$ during the conversion of $\mathrm{NO}_{\mathrm{x}}$ to $\mathrm{NO}_{3}^{-}$atm (Michalski et al., 2003; Morin et al., 2008; Alexander et al., 2009). Using the $\Delta^{17} \mathrm{O}$ signature defined by the following equation (Miller, 2002; Kaiser et al., 2007) enables $\mathrm{NO}_{3}^{-}$atm $\left(\Delta^{17} \mathrm{O}>0\right)$ to be distinguished from $\mathrm{NO}_{3 \text { re }}^{-}\left(\Delta^{17} \mathrm{O}=0\right)$ :

$\Delta^{17} \mathrm{O}=\frac{1+\delta^{17} \mathrm{O}}{\left(1+\delta^{18} \mathrm{O}\right)^{\beta}}-1$,

where the constant $\beta$ is 0.5247 (Miller, 2002; Kaiser et al., 2007), $\delta^{18} \mathrm{O}=R_{\text {sample }} / R_{\text {standard }}-1$ and $R$ is the ${ }^{18} \mathrm{O} /{ }^{16} \mathrm{O}$ ratio (or the ${ }^{17} \mathrm{O} /{ }^{16} \mathrm{O}$ ratio in the case of $\delta^{17} \mathrm{O}$ or the ${ }^{15} \mathrm{~N} /{ }^{14} \mathrm{~N}$ ratio in the case of $\delta^{15} \mathrm{~N}$ ) of the sample and each standard reference material. In addition, $\Delta^{17} \mathrm{O}$ is stable during mass-dependent isotope fractionation processes within surface ecosystems. As a result, while the atmospheric $\delta^{15} \mathrm{~N}$ or $\delta^{18} \mathrm{O}$ signature can be overprinted by biogeochemical processes, we can use $\Delta^{17} \mathrm{O}$ as a conserved tracer of $\mathrm{NO}_{3}^{-}$atm and trace $\mathrm{NO}_{3}^{-}$atm, regardless of its partial removal through denitrification and/or uptake subsequent to deposition.

In our previous study, we determined the $\Delta^{17} \mathrm{O}$ values of nitrate in aerobic groundwater worldwide to trace the fate of $\mathrm{NO}_{3}^{-}$atm that had been deposited onto and passed through natural background watersheds (Nakagawa et al., 2013). The results of that study revealed that nitrate in groundwater had small $\Delta^{17} \mathrm{O}$ values ranging from $-0.2 \%$ o to $+4.5 \%$; therefore, we estimated the average mixing ratio of $\mathrm{NO}_{3}^{-}$atm to total nitrate in the groundwater samples to be $3.1 \%$. Moreover, the concentrations of $\mathrm{NO}_{3}^{-}$atm ranged from less than $0.1 \mu \mathrm{mol} \mathrm{L}{ }^{-1}$ to $8.5 \mu \mathrm{mol} \mathrm{L}{ }^{-1}$, with lower $\mathrm{NO}_{3}^{-}$atm concentrations being obtained for those recharged in forested areas with high coverage of vegetation. Based on these findings, we concluded that most $\mathrm{NO}_{3}^{-}$atm deposited onto healthy forested watersheds had been removed by plants and/or microbes subsequent to deposition.

In this study, we measured temporal variations in the stable isotopic compositions of nitrate in stream water eluted from the forested watershed in the Teshio Experimental Forest in accordance with clear-cutting and strip-cutting to quantify the biogeochemical effects of these activities. In particular, this study focused on the fate of $\mathrm{NO}_{3}^{-}$atm being deposited into the forest ecosystem. Specifically, the $\Delta^{17} \mathrm{O}$ tracer was used to quantify temporal variations in the concentration of $\mathrm{NO}_{3}^{-}$atm in stream water to gain insight into the processes controlling the fate and transport of $\mathrm{NO}_{3}^{-}$atm deposited onto the forested watershed. The results presented herein will increase our understanding of fixed-nitrogen processing and fixed-nitrogen retention efficiencies within forest ecosystems as well.

\section{Experimental section}

\subsection{Site description and management}

The study site has been described in detail by Fukazawa et al. (2006) and Takagi et al. (2009). Clear-cutting of trees and subsequent strip-cutting of understory vegetation were conducted in a cool-temperate forested watershed in the Teshio Experimental Forest of Hokkaido University in northern Japan (Fig. 1; $45^{\circ} 03^{\prime} \mathrm{N}, 142^{\circ} 06^{\prime} \mathrm{E}$ ). Prior to clear-cutting, the predominant overstory species were fir (Abies sachalinensis), birch (Betula ermanii and Betula platyphylla var. japonica), and Mongolian oak (Quercus mongolica var. grosserrata). The forest floor of the study site is covered with dense understory vegetation primarily consisting of dwarf bamboo (mainly Sasa senanensis in flat areas and Sasa kurilensis on steep riparian slopes). The bedrock underlying the site consists of sedimentary rock of the Cretaceous period. The air temperature in the region varies from $-35^{\circ} \mathrm{C}$ to $+35^{\circ} \mathrm{C}$, with an annual mean of $5.6^{\circ} \mathrm{C}$. The annual mean precipitation is $1170 \mathrm{~mm}, 30 \%$ of which is snow. As a result, the site is covered with dense snow from November to March every year.

To evaluate the effects of clear-cutting on $\mathrm{CO}_{2}$ exchange in the forest, a monitoring tower was established in 2001 at the central part of the area (Fig. 1) and net ecosystem production over the forest stands has been monitored as part of a project known as the Carbon Cycle and Larch Growth experiment (CC-LaG) (Takagi et al., 2009). Clear-cutting of trees surrounding the tower with an area of 13.7 ha was conducted from January to March 2003 (Takagi et al., 2009; Fukuzawa et al., 2006). Following clear-cutting, logs were transported outside of the basin, while Sasa spp. were conserved and detritus (including shoots, twigs and leaves) was left in the basin. The Sasa spp. were then strip-cut into $4 \mathrm{~m}$ rows by crushing and spreading in October 2003. The area in which the Sasa spp. were strip-cut accounted for ca. $50 \%$ of the total tree-cut area in the watershed. Larch seedlings were planted in the Sasa spp. strip-cut line immediately after cutting.

\subsection{Water sampling}

Stream water was sampled at a weir located on the outlet (Yatsume-zawa River) of the watershed (Fig. 1) every 2 weeks from June 2002 to December 2005. The total catchment area of the stream was 8 ha, all of which was the clearcutting area of CC-LaG project, except for the riparian area and slope, which had a width of about $13 \mathrm{~m}$ from the stream. After measurement of the $\mathrm{pH}$ using a glass electrode, water samples were filtered through a $0.7 \mu \mathrm{m}$ GF/F filter and kept at $4{ }^{\circ} \mathrm{C}$ for further analysis. Following additional filtering using a $0.2 \mu \mathrm{m}$ membrane filter in the laboratory, the concentrations of major anions $\left(\mathrm{Cl}^{-}, \mathrm{NO}_{3}^{-}, \mathrm{SO}_{4}^{2-}\right)$ and cations $\left(\mathrm{Na}^{+}, \mathrm{NH}_{4}^{+}\right.$, $\mathrm{K}^{+}, \mathrm{Mg}^{2+}, \mathrm{Ca}^{2+}$ ) were measured by ion chromatography 
(DX-500, Dionex Inc., USA). Samples were analyzed within 6 months of sampling and then sealed in $30 \mathrm{~mL}$ polyethylene bottles for further analyses, including measurement of the isotopes reported in this study. The longest storage period between bottling and isotope analysis was 7 years. The ion concentrations of samples collected from June 2002 to December 2004 have been presented in our previous study (Fukuzawa et al., 2006).

\subsection{Isotope analysis}

Prior to isotope analyses, we excluded samples (1) having a residual water volume less than $10 \mathrm{~mL}$, or (2) having nitrate concentrations below the detection limit in this study $\left(0.8 \mu \mathrm{mol} \mathrm{L}{ }^{-1}\right)$. In addition, the nitrate concentration of each stream water sample was determined again by ion chromatography to exclude samples that had been altered during storage. Following screening, a total of one, four, 15, and 18 samples from 2002, 2003, 2004, and 2005, respectively, were analyzed for stable isotopic compositions.

The stable isotopic compositions were determined by converting the nitrate in each sample to $\mathrm{N}_{2} \mathrm{O}$ using the chemical method originally developed to determine the ${ }^{15} \mathrm{~N} /{ }^{14} \mathrm{~N}$ and ${ }^{18} \mathrm{O} /{ }^{16} \mathrm{O}$ ratios of seawater and freshwater nitrate (McIlvin and Altabet, 2005), with slight modifications (Tsunogai et al., 2008; Tsunogai et al., 2010; Konno et al., 2010; Tsunogai et al., 2011; Yamazaki et al., 2011; Nakagawa et al., 2013). Then, the stable isotopic compositions of $\mathrm{N}_{2} \mathrm{O}$ were determined using a continuous-flow isotope ratio massspectrometry (CF-IRMS) system (Tsunogai et al., 2008; Hirota et al., 2010). This system consists of an original helium purge and trap line, a gas chromatograph (Agilent 6890) and a Finnigan MAT 252 (Thermo Fisher Scientific, Waltham, MA, USA) with a modified Combustion III interface (Tsunogai et al., 2000; Tsunogai et al., 2002; Nakagawa et al., 2004; Tsunogai et al., 2005) and a specially designed multi-collector system (Komatsu et al., 2008). For analysis, aliquots of $\mathrm{N}_{2} \mathrm{O}$ were introduced, purified, and then carried continuously into the mass spectrometer via an open split interface, where the isotopologues of $\mathrm{N}_{2} \mathrm{O}^{+}$at $\mathrm{m} / \mathrm{z}$ ratios of 44,45 , and 46 were monitored to determine $\delta^{45}$ and $\delta^{46}$. Each analysis was calibrated using a machine-working reference gas $\left(99.999 \% \mathrm{~N}_{2} \mathrm{O}\right)$ that was introduced into the mass spectrometer via an open split interface according to a definite schedule to correct for sub-daily temporal variations in the mass spectrometry. In addition, a working-standard gas mixture containing a known concentration of $\mathrm{N}_{2} \mathrm{O}$ (ca. $1000 \mathrm{ppm}$ $\mathrm{N}_{2} \mathrm{O}$ in air) that was injected from a sampling loop was analyzed in the same way as the samples at least once a day to correct for daily temporal variations in the mass spectrometry.

Following analyses based on $\mathrm{N}_{2} \mathrm{O}^{+}$monitoring, another aliquot of $\mathrm{N}_{2} \mathrm{O}$ was introduced to determine the $\Delta^{17} \mathrm{O}$ of $\mathrm{N}_{2} \mathrm{O}$ (Komatsu et al., 2008). Using the same procedures as those used in the $\mathrm{N}_{2} \mathrm{O}^{+}$monitoring mode, purified $\mathrm{N}_{2} \mathrm{O}$ was introduced into our original gold tube unit (Komatsu et al., 2008), which was held at $780^{\circ} \mathrm{C}$ for the thermal decomposition of $\mathrm{N}_{2} \mathrm{O}$ to $\mathrm{N}_{2}$ and $\mathrm{O}_{2}$. The produced $\mathrm{O}_{2}$ purified from $\mathrm{N}_{2}$ was then subjected to CF-IRMS to determine the $\delta^{33}$ and $\delta^{34}$ by simultaneous monitoring of $\mathrm{O}_{2}^{+}$isotopologues at $\mathrm{m} / \mathrm{z}$ ratios of 32, 33, and 34. Each analysis was calibrated with a machine-working reference gas $\left(99.999 \% \mathrm{O}_{2}\right.$ gas in a cylinder) that was introduced into the mass spectrometer via an open split interface according to a definite schedule to correct for sub-daily temporal variations in the mass spectrometry. In addition, a working-standard gas mixture containing $\mathrm{N}_{2} \mathrm{O}$ of known concentration (ca. $1000 \mathrm{ppm} \mathrm{N}_{2} \mathrm{O}$ in air) was analyzed in the same way as the samples at least once a day to correct for daily temporal variations in the mass spectrometry.

The values of $\delta^{15} \mathrm{~N}, \delta^{18} \mathrm{O}$, and $\Delta^{17} \mathrm{O}$ for $\mathrm{N}_{2} \mathrm{O}$ derived from the nitrate in each sample were compared with those derived from our local laboratory nitrate standards that had been calibrated using the internationally distributed isotope reference materials (USGS-34 and USGS-35) (Böhlke et al., 2003; Kaiser et al., 2007) to calibrate the $\delta$ values of the sample nitrate to an international scale, as well as to correct for both isotope fractionation during the chemical conversion to $\mathrm{N}_{2} \mathrm{O}$ and the progression of oxygen isotope exchange between the nitrate-derived reaction intermediate and water (ca. $20 \%$ ). All $\delta$ values are expressed relative to air (for nitrogen) and VSMOW (for oxygen) in this paper.

In this study, we adopted the internal standard method (Nakagawa et al., 2013) for accurate calibrations to determine the $\delta^{15} \mathrm{~N}, \delta^{18} \mathrm{O}$ or $\Delta^{17} \mathrm{O}$ values of nitrate. Specifically, we added each of the nitrate standard solutions (containing ca. $10 \mathrm{mmol} \mathrm{L}^{-1}$ nitrate with known $\delta^{15} \mathrm{~N}, \delta^{18} \mathrm{O}$ or $\Delta^{17} \mathrm{O}$ values) to additional aliquots of the samples until the nitrate concentration was three to five times larger than the original. Then we converted it to $\mathrm{N}_{2} \mathrm{O}$ and determined the values of $\delta^{15} \mathrm{~N}, \delta^{18} \mathrm{O}$, or $\Delta^{17} \mathrm{O}$ in a similar manner as was used for each pure sample. After correcting for the contribution of $\mathrm{N}_{2} \mathrm{O}$ from the nitrate in each sample, we obtained the stable isotopic compositions for $\mathrm{N}_{2} \mathrm{O}$ derived from our laboratory nitrate standards. Next, the $\delta^{15} \mathrm{~N}, \delta^{18} \mathrm{O}$, and $\Delta^{17} \mathrm{O}$ values in the samples were simply calibrated using curves generated from the $\mathrm{N}_{2} \mathrm{O}$ derived from the nitrate standards.

The samples had nitrate concentrations of more than $0.8 \mu \mathrm{mol} \mathrm{L}-1$, corresponding to nitrate quantities greater than $20 \mathrm{nmol}$ in a $30 \mathrm{~mL}$ sample, which is sufficient to determine $\delta^{15} \mathrm{~N}, \delta^{18} \mathrm{O}$, and $\Delta^{17} \mathrm{O}$ values with high precision. Thus, all isotopic data presented in this study have an error better than $\pm 0.3 \%$ for $\delta^{15} \mathrm{~N}, \pm 0.5 \%$ for $\delta^{18} \mathrm{O}$, and $\pm 0.2 \%$ or $\Delta^{17} \mathrm{O}$.

Because we used the more precise power law shown in the Eq. (1) to calculate $\Delta^{17} \mathrm{O}$, the estimated $\Delta^{17} \mathrm{O}$ values were somewhat different from those estimated based on traditional linear approximation (Michalski et al., 2002). While the differences were insignificant for most stream water samples evaluated in this study, the differences would be $0.9 \pm 0.2 \%$ o for the $\Delta^{17} \mathrm{O}$ values of $\mathrm{NO}_{3 \mathrm{~atm}}^{-}$. When using the linearly 
approximated $\Delta^{17} \mathrm{O}$ values of $\mathrm{NO}_{3}^{-}$atm available in the literature, we recalculated the $\Delta^{17} \mathrm{O}$ values based on the power law.

Nitrite $\left(\mathrm{NO}_{2}^{-}\right)$in the samples also interferes with the final $\mathrm{N}_{2} \mathrm{O}$ produced from nitrate $\left(\mathrm{NO}_{3}^{-}\right)$, because the chemical method also converts $\mathrm{NO}_{2}^{-}$to $\mathrm{N}_{2} \mathrm{O}$ (McIlvin and Altabet, 2005). Therefore, it was necessary to correct for the contribution of $\mathrm{NO}_{2}^{-}$-derived $\mathrm{N}_{2} \mathrm{O}$ to accurately determine the stable isotopic compositions of the sample nitrate. However, all samples analyzed in this study contained $\mathrm{NO}_{2}^{-}$at concentrations below the detection limit $\left(0.05 \mu \mathrm{mol} \mathrm{L}^{-1}\right)$, which corresponded to $\mathrm{NO}_{2}^{-} / \mathrm{NO}_{3}^{-}$ratios less than $10 \%$; thus, the results were used without any corrections.

The $\delta^{18} \mathrm{O}$ values of $\mathrm{H}_{2} \mathrm{O}$ in the samples were analyzed using cavity ring-down spectroscopy (Picarro L2120-I with an A0211 vaporizer and auto sampler), which had an error of $\pm 0.1 \%$. Both VSMOW and VSLAP were used to calibrate the values to the international scale.

\subsection{Deposition rate of atmospheric nitrate}

Continuous monitoring of the deposition rate of atmospheric nitrate was conducted from April 2008 to March 2012 (FY2008 to FY2011). While total (wet + dry) deposition rate of atmospheric nitrate had been determined in the site using a simple bucket sampler collected monthly during 2002 (Fukuzawa et al., personal communication, 2014), we began more precise monitoring based on the standard EANET methodology, in response to the increase in nitrate concentration in the stream (Fukuzawa et al., 2006). Wet deposition samples were collected weekly at a height of $2.5 \mathrm{~m}$ using a wet only sampler. Nitrate aerosol, nitric acid, and nitrous acid were collected for every 3 weeks from the monitoring tower at a height of $30 \mathrm{~m}$ (Fig. 1) using the filter pack method (flow rate $=4 \mathrm{~L} \mathrm{~min}^{-1}$ ) and a PM2.5 impactor (Noguchi et al., 2007b). Nitrogen oxides $\left(\mathrm{NO}_{2}\right.$ and $\left.\mathrm{NO}\right)$ were collected monthly (every 3 or 6 weeks) from a height of $1.5 \mathrm{~m}$ using an Ogawa passive sampler. These components were measured by ion chromatography (Dionex ICS-2000/1500) at the laboratory of the Institute of Environmental Science, Hokkaido Research Organization, and the results were used to estimate the dry deposition rates of nitrate by the inferential method using a mean tree height of 3.0 m for FY2008-2009 and 4.0 for FY2010-2011 (Noguchi et al., 2011).

\section{Results and discussion}

\subsection{Temporal variations in stream water nitrate}

The average stream nitrate concentration was $0.9 \mu \mathrm{mol} \mathrm{L}-1$ in 2002 (June to December) and $0.7 \mu \mathrm{mol} \mathrm{L}^{-1}$ in 2003 (annual average), while the maximum nitrate concentration was $2.7 \mu \mathrm{mol} \mathrm{L}-1$ in 2002 and $3.1 \mu \mathrm{mol} \mathrm{L}^{-1}$ in 2003. The maximum nitrate concentration was much lower than the aver-

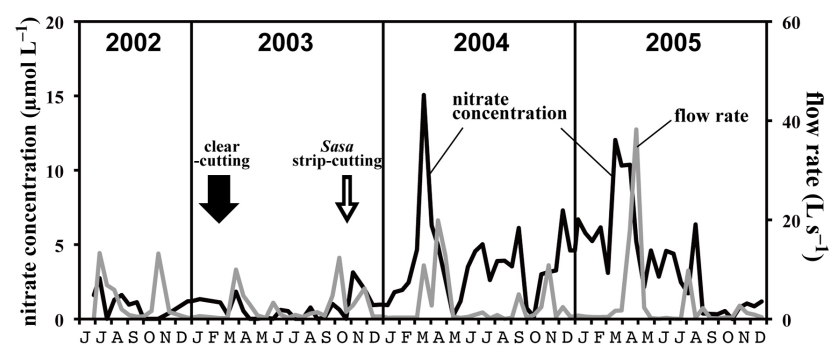

Figure 2. Temporal variations in nitrate concentrations in stream water (black line), together with those of flow rate of the stream water (grey line). Solid and open arrows denote the period of clearcutting of trees and strip-cutting of Sasa, respectively. The temporal variations in nitrate concentration from June 2002 to the end of 2004 were previously presented by Fukuzawa et al. (2006).

age nitrate concentration of wet deposition in a background area of eastern Asia (around $10 \mu \mathrm{mol} \mathrm{L}^{-1}$ ) (EANET, 2013). The low and stable stream nitrate concentration during 20022003 implied that atmospheric nitrate had been effectively removed from the forested watershed, and that rain or snow events had little direct impact on the stream nitrate concentration. However, as discussed in Fukuzawa et al. (2006), a significant increase in stream nitrate concentration was observed in 2004, probably in response to strip-cutting of the understory dwarf bamboo, S. senanensis, in October 2003 (Fig. 2). The average nitrate concentration increased to $3.8 \mu \mathrm{mol} \mathrm{L}^{-1}$ in 2004 (annual average) and $3.8 \mu \mathrm{mol} \mathrm{L}^{-1}$ in 2005 (annual average). The maximum nitrate concentration also increased to $15 \mu \mathrm{mol} \mathrm{L}^{-1}$ in 2004 and $12 \mu \mathrm{mol} \mathrm{L}^{-1}$ in 2005 (Fig. 2). These findings indicate that strip-cutting had significant impacts on nitrate dynamics in the forest ecosystem from 2004 until at least the end of 2005.

Temporal variations in the values of $\delta^{15} \mathrm{~N}, \delta^{18} \mathrm{O}$, and $\Delta^{17} \mathrm{O}$ of nitrate in accordance with the variations in nitrate concentration since January 2003 are presented in Fig. 3. The arithmetic average and $1 \sigma$ variation for the $\delta^{15} \mathrm{~N}$ and $\delta^{18} \mathrm{O}$ values of nitrate were $+1.3 \pm 3.3 \%$ and $+3.4 \pm 11.1 \%$, respectively (Fig. 3). While the average values of $\delta^{15} \mathrm{~N}$ and $\delta^{18} \mathrm{O}$ were typical of nitrate in natural stream water, the range of $\delta^{18} \mathrm{O}$ values was one of the largest ever reported in natural stream water during continuous monitoring (Burns and Kendall, 2002; Campbell et al., 2002; Ohte et al., 2004; Hales et al., 2007; Barnes et al., 2008; Burns et al., 2009; Tobari et al., 2010; Ohte et al., 2010; Barnes and Raymond, 2010; Nestler et al., 2011; Curtis et al., 2011; Pellerin et al., 2012; Yue et al., 2013; Ohte, 2013; Lohse et al., 2013; Thibodeau et al., 2013). The arithmetic average and maximum $\Delta^{17} \mathrm{O}$ values of nitrate were $+2.2 \pm 3.5 \%$ and $+14.3 \%$, respectively (Fig. 3). The $\Delta^{17} \mathrm{O}$ value of $+14.3 \%$ corresponds to the highest $\Delta{ }^{17} \mathrm{O}$ value ever reported for dissolved nitrate in natural stream water (Michalski et al., 2004; Tsunogai et al., 2010; Dejwakh et al., 2012; Liu et al., 2013), as well as that in soil solution (Michalski et al., 2004; Costa et al., 2011). 

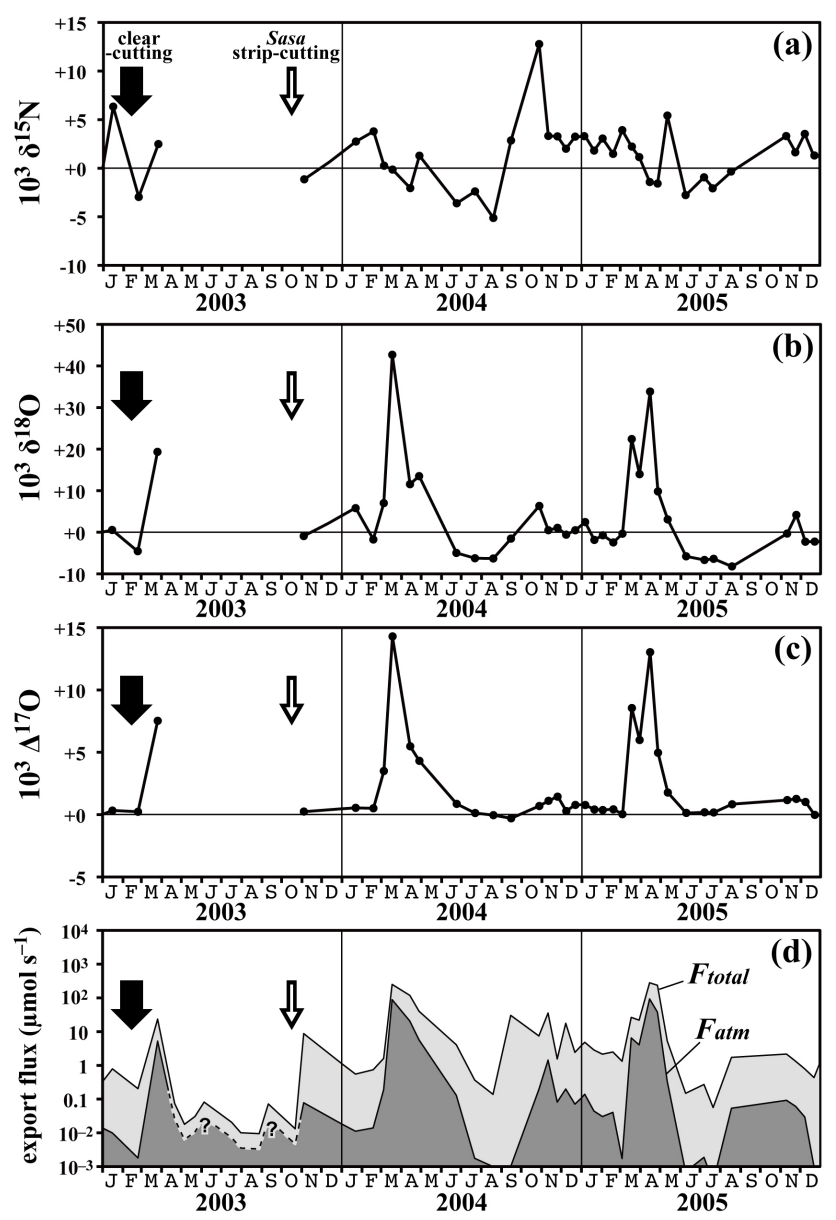

Figure 3. Temporal variations in the values of $\delta^{15} \mathrm{~N}(\mathbf{a}), \delta^{18} \mathrm{O}(\mathbf{b})$, and $\Delta^{17} \mathrm{O}(\mathbf{c})$ of nitrate in the stream water, together with those in the export fluxes of nitrate $\left(F_{\text {total }}\right)$ and atmospheric nitrate $\left(F_{\text {atm }}\right)$ on a logarithmic scale (d). Solid and open arrows denote the period of clear-cutting of trees and strip-cutting of Sasa, respectively.

One of the striking features of the large temporal variations of $\delta^{18} \mathrm{O}$ and $\Delta^{17} \mathrm{O}$ was the enhancement of both $\delta^{18} \mathrm{O}$ and $\Delta^{17} \mathrm{O}$ in spring, especially in the years following stripcutting. Enrichment of nitrate concentration was detected in spring of 2004 and 2005, probably in response to the spring snowmelt after strip-cutting (Fig. 2). The results of the present study using stable isotopes revealed that these enriched nitrate levels were accompanied by elevated values of both $\delta^{18} \mathrm{O}$ and $\Delta^{17} \mathrm{O}$. Atmospheric nitrate is characterized by elevated values of both $\delta^{18} \mathrm{O}$ and $\Delta^{17} \mathrm{O}$ to up to $+110 \%$ (Durka et al., 1994; Kendall, 1998; Savarino et al., 2007; Morin et al., 2008) and $+45 \%$ (Savarino et al., 2007; McCabe et al., 2007; Morin et al., 2008), respectively. In addition, atmospheric nitrate is currently the only source of nitrate that shows $\Delta^{17} \mathrm{O}$ values larger than $0 \%$. Accordingly, atmospheric nitrate might be the source of nitrate enrichment during the spring snowmelt. However, the temporal variations in $\delta^{15} \mathrm{~N}$ values were independent from the variations in $\delta^{18} \mathrm{O}$ and $\Delta^{17} \mathrm{O}$ (Fig. 3). Overall, these findings indicate that the major process controlling the $\delta^{15} \mathrm{~N}$ values appears to be different from those controlling the $\delta^{18} \mathrm{O}$ and $\Delta^{17} \mathrm{O}$ values.

Conversely, temporal variations in the $\delta^{18} \mathrm{O}$ values of $\mathrm{H}_{2} \mathrm{O}$ was small and independent from variations in the $\delta^{18} \mathrm{O}$ and $\Delta{ }^{17} \mathrm{O}$ values of nitrate, with an arithmetic average and $1 \sigma$ variation of $-11.0 \pm 0.7 \%$, which is typical of stream water in the area (Mizota and Kusakabe, 1994). The annual flow volume of the stream was stable at around $8 \times 10^{8} \mathrm{~L} \mathrm{yr}^{-1} \mathrm{ev}-$ ery year as well (Fig. 2), which corresponds to more than $80 \%$ of the total precipitation in the catchment. Considering the evaporative loss of water from the catchment area, water loss via groundwater flow must be very low for the watershed. Thus, we assumed that the studied stream was the only channel through which nitrate was eluted from the catchment area for later discussions.

\section{2 $\delta^{18} \mathrm{O}$ and $\delta^{15} \mathrm{~N}$ values of atmospheric nitrate}

To further verify that $\mathrm{NO}_{3}^{-}$atm was responsible for the elevated $\Delta^{17} \mathrm{O}$ values in the samples by up to $+14.3 \%$ in spring 2004 and 2005, the $\delta^{15} \mathrm{~N}$ and $\delta^{18} \mathrm{O}$ values of nitrate in the samples were plotted as a function of $\Delta^{17} \mathrm{O}$ (Fig. 4). Because $\mathrm{NO}_{3}^{-}$atm is enriched in both ${ }^{18} \mathrm{O}$ and ${ }^{17} \mathrm{O}$ simultaneously (Michalski et al., 2003; Tsunogai et al., 2010), ${ }^{18} \mathrm{O}$-enrichment was expected for samples showing elevated $\Delta^{17} \mathrm{O}$ values if $\mathrm{NO}_{3}^{-}$atm was responsible for the increased levels. As shown in Fig. 4b, the $\delta^{18} \mathrm{O}$ values in the samples showed strong linear correlation with the $\Delta^{17} \mathrm{O}$ values $\left(r^{2}=0.92, p<0.001\right)$. Additionally, when we extrapolated the linear correlation to the $\Delta^{17} \mathrm{O}$ value of $\mathrm{NO}_{3}^{-}$atm obtained through continuous monitoring on Rishiri Island ( $+26 \pm 3 \%$; Tsunogai et al., 2010), which is located $50 \mathrm{~km}$ northwest of the study site (Fig. 1) (Noguchi et al., 2007a; Tsunogai et al., 2010), we obtained $\delta^{18} \mathrm{O}=+79 \pm 20 \%$, which correspond to the $\delta^{18} \mathrm{O}$ values for $\mathrm{NO}_{3}^{-}$atm (Durka et al., 1994; Morin et al., 2009; Alexander et al., 2009; Tsunogai et al., 2010). These findings indicated that an increase in the export flux of $\mathrm{NO}_{3}^{-}$atm was primarily responsible for nitrate enrichment in stream water during spring of 2004 and 2005. The $\delta^{15} \mathrm{~N}$ values of nitrate are consistent with this conclusion as well. While the variation in $\delta^{15} \mathrm{~N}$ values showed little correlation with $\Delta^{17} \mathrm{O}$ (Fig. 4), the $\delta^{15} \mathrm{~N}$ values of those showing $\Delta^{17} \mathrm{O}$ values more than $+5 \%$ o were plotted around $-0.7 \pm 2.7 \%$, which almost corresponds with the annual average $\delta^{15} \mathrm{~N}$ value of $\mathrm{NO}_{3}^{-}$atm determined in Rishiri Island (-1.1\%o; Tsunogai et al., 2010). Atmospheric nitrate was highly responsible for the elevated $\Delta^{17} \mathrm{O}$ values.

\section{$3.3 \quad \delta^{18} \mathrm{O}$ and $\delta^{15} \mathrm{~N}$ values of remineralized nitrate}

The average $\delta^{18} \mathrm{O}$ value of $\mathrm{NO}_{3}^{-}$re produced through nitrification in the forested watershed was determined to be -3.6 $\pm 0.7 \%$ based on the intercept $\left(\Delta^{17} \mathrm{O}=0\right)$ of the plot of $\Delta^{17} \mathrm{O}$ and $\delta^{18} \mathrm{O}$ shown in Fig. 4b. A similar $\delta^{18} \mathrm{O}$ value of 

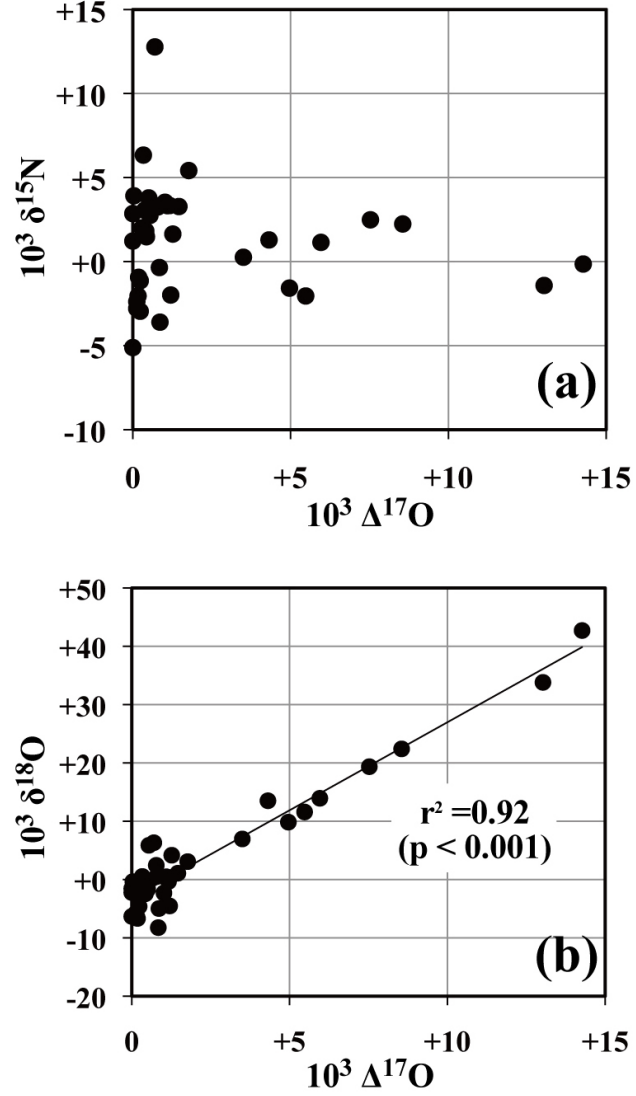

Figure 4. Relationship between $\Delta^{17} \mathrm{O}$ and $\delta^{15} \mathrm{~N}$ of nitrate (a) and $\Delta^{17} \mathrm{O}$ and $\delta^{18} \mathrm{O}$ of nitrate (b) in stream water samples.

$-4.2 \pm 2.4 \%$ o was obtained for $\mathrm{NO}_{3}^{-}$re produced through nitrification in a forested watershed on nearby Rishiri Island, where the $\mathrm{H}_{2} \mathrm{O}$ showed $\delta^{18} \mathrm{O}$ values of around $-13 \%$ obased on the linear relationship between the $\Delta^{17} \mathrm{O}$ and $\delta^{18} \mathrm{O}$ of nitrate dissolved in both groundwater and stream water on the island (Tsunogai et al., 2010). Conversely, Spoelstra et al. (2007) proposed much higher $\delta^{18} \mathrm{O}$ values of +3.1 to $+10.1 \%$ with a mean value of $+5.2 \%$ for nitrate produced through nitrification in soils based on in vitro incubation experiments using soils containing $\mathrm{H}_{2} \mathrm{O}$ with $\delta^{18} \mathrm{O}$ values around $-10 \%$. Similar high $\delta^{18} \mathrm{O}$ values of nitrate were also obtained for nitrate produced through nitrification in soils in several past studies based on in vitro soil-incubation experiments (Burns and Kendall, 2002) and calculations (Durka et al., 1994).

During the conversion of ammonium to nitrate by chemolithoautotrophic bacteria, two oxygen atoms originate from $\mathrm{H}_{2} \mathrm{O}$ and one from $\mathrm{O}_{2}$ (Aleem et al., 1965; Andersson and Hooper, 1983; Kumar et al., 1983). In recent laboratory studies, the kinetic isotope effects during incorporation of $\mathrm{O}$ atoms were estimated to be $+20.4 \pm 2.3 \%$ o for ammonia oxidation $\left(\mathrm{O}_{2}\right.$ plus $\mathrm{H}_{2} \mathrm{O}$ incorporation $)$ and $+8.6 \pm 2.3 \%$ o for incorporation of $\mathrm{H}_{2} \mathrm{O}$ during nitrite oxidation (Buchwald et al., 2012). Furthermore, the equilibrium isotope effect during abiotic $\mathrm{O}$ atom exchange between nitrite and $\mathrm{H}_{2} \mathrm{O}$ was estimated to be $+12.5 \pm 1.5 \%$ (Casciotti et al., 2007). Based on the $\delta^{18} \mathrm{O}$ value of atmospheric $\mathrm{O}_{2}(+23.5 \%)$ and the average $\delta^{18} \mathrm{O}$ value of the stream water in the study area $(-11 \%$ ) , a $\delta^{18} \mathrm{O}$ value of $-3.4 \pm 5.8 \%$ for $\mathrm{NO}_{3}^{-}$re was anticipated, which corresponds with the value obtained. We concluded that values around $-3.6 \%$ represented the $\delta^{18} \mathrm{O}$ value of $\mathrm{NO}_{3}^{-}$re produced through nitrification in the forest ecosystem, where $\mathrm{H}_{2} \mathrm{O}$ showed $\delta^{18} \mathrm{O}$ values around $-11 \%$.

Either the slight contribution of $\mathrm{NO}_{3}^{-}$atm or environmental differences between in vitro and in situ samples might be responsible for the higher $\delta^{18} \mathrm{O}$ values of nitrate produced through nitrification in soils obtained in past estimates. Differences in some environmental parameters of soils in the watersheds investigated in this study from those used in past experiments could also be responsible. Accordingly, studies using additional data describing the values of both $\delta^{18} \mathrm{O}$ and $\Delta^{17} \mathrm{O}$ of nitrate eluted from various watersheds and generated through soil-incubation experiments are warranted.

The average $\delta^{15} \mathrm{~N}$ value of $\mathrm{NO}_{3}^{-}$re was determined to be $+1.5 \pm 3.6 \%$ from those having $\Delta^{17} \mathrm{O}$ values less than $1 \%$, which was much greater variance than that of $\delta^{18} \mathrm{O}$. While samples with high $\Delta^{17} \mathrm{O}$ values $\left(\Delta^{17} \mathrm{O}>+3 \%\right.$ ) had $\delta^{15} \mathrm{~N}$ values that showed little dispersion, samples with low $\Delta^{17} \mathrm{O}$ values $\left(\Delta^{17} \mathrm{O}<+3 \%\right.$ ) showed large dispersions (Fig. 4a). The presence of highly variable $\delta^{15} \mathrm{~N}$ values only in low $\Delta^{17} \mathrm{O}$ stream nitrate implied that the $\delta^{15} \mathrm{~N}$ values of $\mathrm{NO}_{3}^{-}$re produced in the studied watershed were highly variable.

To clarify the major process controlling the $\delta^{15} \mathrm{~N}$ values of $\mathrm{NO}_{3}^{-}$re, we estimated the endmember $\delta^{15} \mathrm{~N}$ and $\delta^{18} \mathrm{O}$ values of $\mathrm{NO}_{3}^{-}$re $\left(\delta^{15} \mathrm{~N}_{\mathrm{re}}\right.$ and $\left.\delta^{18} \mathrm{O}_{\mathrm{re}}\right)$ for each sample by correcting the contribution of $\mathrm{NO}_{3}^{-}$atm using each $\Delta^{17} \mathrm{O}$ value, as shown in equations (2), (3), and (4):

$$
\begin{aligned}
\frac{C_{\mathrm{atm}}}{C_{\text {total }}} & =\frac{\Delta^{17} \mathrm{O}}{\Delta^{17} \mathrm{O}_{\mathrm{atm}}}, \\
\delta^{15} \mathrm{~N}_{\mathrm{re}} & =\frac{C_{\text {total }} \times \delta^{15} \mathrm{~N}-C_{\mathrm{atm}} \times \delta^{15} \mathrm{~N}_{\mathrm{atm}}}{C_{\text {total }}-C_{\mathrm{atm}}} \\
\delta^{18} \mathrm{O}_{\mathrm{re}} & =\frac{C_{\text {total }} \times \delta^{18} \mathrm{O}-C_{\mathrm{atm}} \times \delta^{18} \mathrm{O}_{\mathrm{atm}}}{C_{\text {total }}-C_{\mathrm{atm}}},
\end{aligned}
$$

where $C_{\text {atm }}$ and $C_{\text {total }}$ denote the concentration of $\mathrm{NO}_{3}^{-}$atm and $\mathrm{NO}_{3}^{-}$in each water sample, respectively, and $\delta^{15} \mathrm{~N}_{\mathrm{atm}}$, $\delta^{18} \mathrm{O}_{\mathrm{atm}}$, and $\Delta^{17} \mathrm{O}_{\mathrm{atm}}$ denote $\delta^{15} \mathrm{~N}, \delta^{18} \mathrm{O}$, and $\Delta^{17} \mathrm{O}$ values of $\mathrm{NO}_{3}^{-}$atm, respectively. As for the values of $\delta^{15} \mathrm{~N}_{\mathrm{atm}}$, $\delta^{18} \mathrm{O}_{\mathrm{atm}}$, and $\Delta^{17} \mathrm{O}_{\mathrm{atm}}$, we used the annual average values obtained through continuous monitoring on Rishiri Island $\left(\delta^{15} \mathrm{~N}_{\mathrm{atm}}=-1.1 \% o, \quad \delta^{18} \mathrm{O}_{\mathrm{atm}}=+87.1 \%\right.$, and $\Delta \Delta^{17} \mathrm{O}_{\mathrm{atm}}=$ $+26.2 \%$; Tsunogai et al., 2010).

While most samples showed positive $\Delta^{17} \mathrm{O}$ values, three showed negative $\Delta^{17} \mathrm{O}$ values as low as $-0.2 \%$, which prevented estimation of $C_{\text {atm }}$ using equation (2). Because the $\Delta{ }^{17} \mathrm{O}$ value of tropospheric $\mathrm{O}_{2}$ is around $-0.2 \%$ (Luz and 


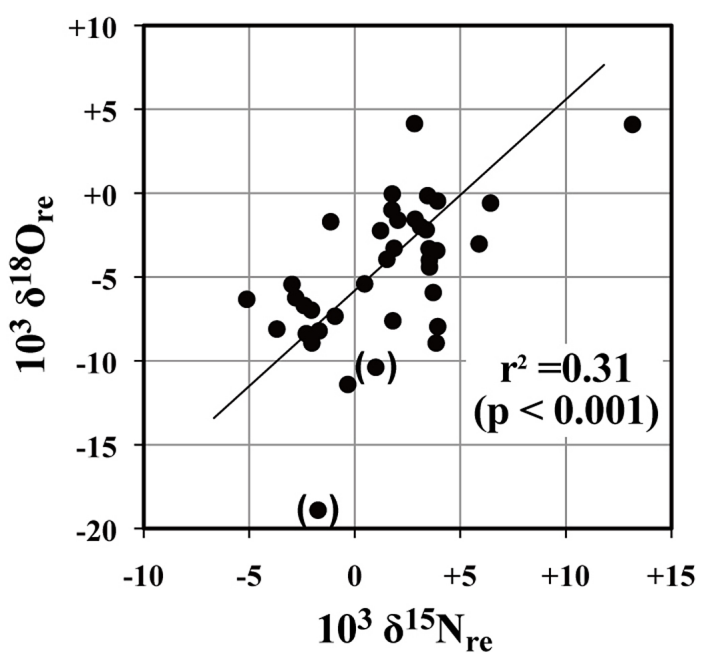

Figure 5. Relationship between estimated $\delta^{15} \mathrm{~N}$ and $\delta^{18} \mathrm{O}$ of remineralized nitrate in stream water samples $\left(\delta^{15} \mathrm{~N}_{\mathrm{re}}\right.$ and $\delta^{18} \mathrm{O}_{\mathrm{re}}$, respectively). See text for the detailed processes used to obtain the values. Data points obtained from samples with high $\Delta^{17} \mathrm{O}$ values $(>+10 \%)$ are shown in parentheses to indicate that they could include large errors.

Barkan, 2000), the contribution of oxygen atoms derived from tropospheric $\mathrm{O}_{2}$ during the production of $\mathrm{NO}_{3}^{-}$re from ammonium or organic nitrogen could be partly responsible for the observed $\Delta^{17} \mathrm{O}$ values less than $0 \%$. However, even if the contribution was significant, the possible $\Delta^{17} \mathrm{O}$ value of produced $\mathrm{NO}_{3}^{-}$re would include $0 \%$ within the error of our analytical precision $( \pm 0.2 \%$ ). Accordingly, $0 \%$ o was used for the $\Delta^{17} \mathrm{O}$ value of $\mathrm{NO}_{3}^{-}$re and observed $\Delta^{17} \mathrm{O}$ values less than $0 \%$ are considered to be $0 \%$ for the remainder of this paper.

The relationship between the estimated $\delta^{15} \mathrm{~N}_{\mathrm{re}}$ and $\delta^{18} \mathrm{O}_{\mathrm{re}}$ is presented in Fig. 5. It should be noted that all estimated $\delta^{15} \mathrm{~N}_{\mathrm{re}}$ values were nearly identical to the observed $\delta^{15} \mathrm{~N}$ values owing to small differences between $\delta^{15} \mathrm{~N}_{\mathrm{re}}$ and $\delta^{15} \mathrm{~N}_{\mathrm{atm}}$. The primary goal of estimating $\delta^{18} \mathrm{O}_{\mathrm{re}}$ is to discuss the reason for large variations in $\delta^{15} \mathrm{~N}_{\text {re }}$ (and thus $\delta^{15} \mathrm{~N}$ ) of nitrate in stream water. Additional determinations on the $\Delta^{17} \mathrm{O}$ values of nitrate together with $\delta^{18} \mathrm{O}$ enable us to correct the contribution of $\mathrm{NO}_{3}^{-}$atm from the determined values of $\delta^{18} \mathrm{O}$ and to use the corrected values $\left(\delta^{18} \mathrm{O}_{\mathrm{re}}\right)$ for discussing the behavior of $\mathrm{NO}_{3}^{-}$re. Unlike $\Delta^{17} \mathrm{O}_{\text {atm }}$, the values of $\delta^{18} \mathrm{O}_{\text {atm }}$ used in the calculation could have been altered within the forest ecosystem subsequent to deposition; therefore, we should consider errors up to $20 \%$ (as presented in Sect. 3.2) in the values of $\delta^{18} \mathrm{O}_{\mathrm{atm}}$. While the errors in the calculated $\delta^{18} \mathrm{O}_{\mathrm{re}}$ values were small for the samples showing low $\Delta^{17} \mathrm{O}$ values, the errors were large for those having high $\Delta^{17} \mathrm{O}$ values. As a result, those having high $\Delta^{17} \mathrm{O}$ values of more than $+10 \%$ o are shown in parentheses to denote that they were excluded from subsequent discussions.
As clearly presented in the figure, $\delta^{15} \mathrm{~N}_{\text {re }}$ and $\delta^{18} \mathrm{O}_{\text {re }}$ were linearly correlated with a slope of $+1.23 \pm 0.45\left(r^{2}=0.31\right.$, $p<0.001)$. As a result, both $\delta^{15} \mathrm{~N}_{\mathrm{re}}$ and $\delta^{18} \mathrm{O}_{\mathrm{re}}$ varied simultaneously in the stream water samples. Partial removal of nitrate through denitrification has been shown to be a representative process that enhances both $\delta^{15} \mathrm{~N}$ and $\delta^{18} \mathrm{O}$ in residual nitrate simultaneously (Amberger and Schmidt, 1987). Previous studies showed that partial removal of nitrate through assimilation by plants and/or microbes could be an alternative process leading to enrichment of both $\delta^{15} \mathrm{~N}$ and $\delta^{18} \mathrm{O}$ in residual nitrate, while the fractionation was found to be small or negligible in general (Högberg, 1997; Kendall, 1998). Denitrification is a more plausible cause of the observed variation in both $\delta^{15} \mathrm{~N}_{\mathrm{re}}$ and $\delta^{18} \mathrm{O}_{\mathrm{re}}$. Theoretical and laboratory studies have suggested that denitrification results in $2: 1$ fractionation of $\delta^{15} \mathrm{~N}: \delta^{18} \mathrm{O}$ (Amberger and Schmidt, 1987; Aravena and Robertson, 1998), but recent studies proposed a $1: 1$ ratio as well (Granger et al., 2008). Thus, although other minor factors could have changed $\delta^{15} \mathrm{~N}_{\mathrm{re}}$ and/or $\delta^{18} \mathrm{O}_{\mathrm{re}}$, the linear correlation between $\delta^{15} \mathrm{~N}_{\mathrm{re}}$ and $\delta^{18} \mathrm{O}_{\mathrm{re}}$ in Fig. 5 implies that $\delta^{15} \mathrm{~N}_{\mathrm{re}}$ (and thus $\delta^{15} \mathrm{~N}$ of nitrate in stream water) primarily represented the progress of denitrification in soils prior to elution into stream water.

As a result, temporal variations in the values of both $\delta^{15} \mathrm{~N}_{\mathrm{re}}$ (and thus $\delta^{15} \mathrm{~N}$ of nitrate in stream water) can be a tracer to quantify the effects of strip-cutting on the progress of denitrification in soils of the watershed. However, we did not observe any significant variations in $\delta^{15} \mathrm{~N}_{\mathrm{re}}$ values in accordance with strip-cutting in the present study. This was likely because only five $\delta^{15} \mathrm{~N}_{\mathrm{re}}$ data points were available prior to strip-cutting $(n=5)$. Accordingly, additional studies generating more nitrate $\delta^{15} \mathrm{~N}_{\text {re }}$ data should be conducted to determine if strip-cutting impacts the progression of denitrification in soils.

Conversely, we observed clear depletion of the $\delta^{15} \mathrm{~N}_{\mathrm{re}}$ values in summer (June, July, and August) when compared with the other seasons (Fig. 3). Specifically, the average $\delta^{15} \mathrm{~N}_{\mathrm{re}}$ value was $-2.5 \pm 1.6 \%$ in summer $(n=7)$, while it was $+2.2 \pm 3.0 \%$ o $(n=34)$ during the other seasons $(p<0.001$, $t$ value $=8.0$ ). A significant positive relationship between soil temperature and gross nitrification rates was observed in previous studies (Breuer et al., 2002; Zaman and Chang, 2004; Hoyle et al., 2006). Active nitrification during summer might reduce the relative progress of denitrification within the total nitrate pool in soils.

\subsection{Quantifying the effects of strip-cutting on nitrate dynamics}

As discussed in Sect. 3.1, a significant increase in stream nitrate concentration was observed in spring of 2004 and 2005, probably in response to the strip-cutting of understory dwarf bamboo, S. senanensis, in October 2003. In the present study, the $\Delta^{17} \mathrm{O}$ tracer of nitrate revealed that strip-cutting in October 2003 had a significant impact on $C_{\text {atm }}$ as well. While 
the maximum stream $C_{\text {atm }}$ was only $0.53 \mu \mathrm{mol} \mathrm{L}^{-1}$ in 2003 , a significant increase in $C_{\text {atm }}$ to $8.2 \mu \mathrm{mol} \mathrm{L}^{-1}$ was observed in spring of 2004, probably in response to strip-cutting. A similar increase in stream $C_{\text {atm }}$ up to $3.9 \mu \mathrm{mol} \mathrm{L}^{-1}$ was also observed in spring of 2005. To quantify the effects of the strip-cutting on processes regulating the elution of $\mathrm{NO}_{3}^{-}$atm, the daily elution rate of $\mathrm{NO}_{3}^{-}$atm $\left(F_{\mathrm{atm}}\right)$ was calculated for each day on which the $\Delta^{17} \mathrm{O}$ value of nitrate was determined from each concentration of $\mathrm{NO}_{3}^{-}$atm $\left(C_{\text {atm }}\right)$ and the daily flow rate of stream water $(\mathrm{V})$ by applying equation $(5)$ :

$F_{\text {atm }}=C_{\text {atm }} \times V$.

There were only four $C_{\text {atm }}$ data points for 2003 because most of the $C_{\text {total }}$ in 2003 were too low (less than $0.1 \mu \mathrm{mol} \mathrm{L}{ }^{-1}$ ) to determine the $\Delta^{17} \mathrm{O}$ values (Fig. 2). However, if the $C_{\text {total }}$ is less than $0.1 \mu \mathrm{mol} \mathrm{L}{ }^{-1}$, the associated $C_{\text {atm }}$ must be less than $0.1 \mu \mathrm{mol} \mathrm{L}{ }^{-1}$ as well, regardless of the $\Delta^{17} \mathrm{O}$ values. To estimate the upper limit of $C_{\text {atm }}$ and thus the upper limit of $F_{\text {atm }}$ for 2003, we applied the maximum $\Delta^{17} \mathrm{O}$ value of nitrate in stream water observed in this study $\left(\Delta^{17} \mathrm{O}=+14.3 \%\right.$ o $)$ as the maximum $\Delta^{17} \mathrm{O}$ value of nitrate for samples showing $C_{\text {total }}$ less than $0.1 \mu \mathrm{mol} \mathrm{L}^{-1}$ in $2003(n=9)$.

The daily elution fluxes of $\mathrm{NO}_{3}^{-}\left(F_{\text {total }}\right)$ and $\mathrm{NO}_{3}^{-}$re $\left(F_{\text {re }}\right)$ were also calculated from both the $\mathrm{NO}_{3}^{-}$concentration $\left(C_{\text {total }}\right)$ and the daily average flow rate of the stream water (V) by applying Eqs. (6) and (7):

$$
\begin{aligned}
& F_{\text {total }}=C_{\text {total }} \times V \\
& F_{\text {re }}=F_{\text {total }}-F_{\text {atm }} .
\end{aligned}
$$

The temporal variation of $F_{\text {atm }}$ and the $F_{\text {total }}$ are plotted in Fig. 3d. As shown in the figure, enrichment of $F_{\text {atm }}$ occurred during spring from 2003 to 2005 . More than $90 \%$ of $\mathrm{NO}_{3 \text { atm }}^{-}$eluted in March, April, and May each year. Direct contribution of $\mathrm{NO}_{3}^{-}$atm from snow pack to the stream must be responsible for this phenomenon. Similar spring enrichment of $F_{\text {atm }}$ due to snowmelt has been observed through continuous monitoring of $\delta^{18} \mathrm{O}$ of nitrate in runoff (Kendall et al., 1995; Ohte et al., 2004; Piatek et al., 2005; Pellerin et al., 2012). While spring $F_{\text {atm }}$ enrichment was observed from 2003 to 2005, regardless of strip-cutting, the levels became much higher after strip-cutting. The maximum $F_{\text {atm }}$ increased from $5.3 \mu \mathrm{mol} \mathrm{s}^{-1}$ in 2003 to $88.6 \mu \mathrm{mol} \mathrm{s}^{-1}$ in 2004 and $93.3 \mu \mathrm{mol} \mathrm{s}^{-1}$ in 2005. Additionally, maximum $F_{\mathrm{re}}$ increased from $13.0 \mu \mathrm{mol} \mathrm{s}^{-1}$ in 2003 to $77.8 \mu \mathrm{mol} \mathrm{s}^{-1}$ in 2004 and $161.5 \mu \mathrm{mol} \mathrm{s}^{-1}$ in 2005 .

Conversely, $F_{\text {atm }}$ was always small during the other seasons, even after strip-cutting. Most of the nitrate being exported from the watershed during seasons other than spring was $\mathrm{NO}_{3}^{-}$re : those retained in the forested ecosystem as either organic $\mathrm{N}$ or ammonium and then been converted to nitrate via microbial nitrification. $F_{\text {atm }}$ was especially low during summer. $F_{\text {re }}$ was reduced during summer as well (Fig. 3).

As discussed above, $\delta^{15} \mathrm{~N}_{\mathrm{re}}$ depletion implied active nitrification during summer. The combination of both active
Table 1. Temporal variations in the export flux per unit area of the catchment $\left(\mathrm{mmol} \mathrm{m}^{-2} \mathrm{yr}^{-1}\right)$ of atmospheric nitrate $\left(M_{\mathrm{atm}}\right)$, together with those of remineralized nitrate $\left(M_{\mathrm{re}}\right)$, total nitrate ( $\left.M_{\text {total }}\right)$, and $M_{\text {atm }} / M_{\text {total }}$ ratio. Changes relative to 2003 are presented in parentheses.

\begin{tabular}{llll}
\hline & 2003 & 2004 & 2005 \\
\hline$M_{\text {atm }}$ & $0.13 \pm 0.04$ & 2.6 & 2.1 \\
& $(1)$ & $(16-30)$ & $(13-24)$ \\
$M_{\text {re }}$ & $0.88 \pm 0.04$ & 3.7 & 4.8 \\
& $(1)$ & $(4)$ & $(5-6)$ \\
$M_{\text {total }}$ & 1.0 & 6.4 & 7.0 \\
& $(1)$ & $(6.3)$ & $(6.9)$ \\
$M_{\text {atm }} / M_{\text {total }}$ & $9-16 \%$ & $41 \%$ & $31 \%$ \\
\hline
\end{tabular}

nitrification in soil and active nitrate consumption through assimilation by plants and/or microbes resulted in both a reduction and rapid turnover of the nitrate pool in soil, and thus a reduction in the elution rate of both $\mathrm{NO}_{3}^{-}$atm (mostly) and $\mathrm{NO}_{3}^{-}$re (partly) during summer. When compared with summer, a slight increase in $F_{a t m}$ was observed in fall and winter. The decrease in nitrification and nitrate consumption in soils increased the direct drainage rate of $\mathrm{NO}_{3}^{-}$atm.

We can obtain the annual export flux of $\mathrm{NO}_{3}^{-}$atm per unit area of the catchment $\left(M_{\mathrm{atm}}\right)$ by integrating the $F_{\mathrm{atm}}$ values for each year of the observation using the equation (8).

$M_{\mathrm{atm}}=\frac{\sum F_{\mathrm{atm}}(t) \times \Delta t}{S}$,

where $S$ denote the total catchment area ( 8 ha). We can obtain the annual export flux for $\mathrm{NO}_{3}^{-}\left(M_{\text {total }}\right)$ and $\mathrm{NO}_{3}^{-}$re $\left(M_{\mathrm{re}}\right)$ by integrating $F_{\text {re }}$ and $F_{\text {total }}$ for each year of the observation using Eqs. (9) and (10).

$$
\begin{gathered}
M_{\text {total }}=\frac{\sum F_{\text {total }}(t) \times \Delta t}{S} \\
M_{\mathrm{re}}=\frac{\sum F_{\mathrm{re}}(t) \times \Delta t}{S}
\end{gathered}
$$

The estimated $M_{\mathrm{atm}}, M_{\mathrm{re}}$, and $M_{\text {total }}$ for 2003 to 2005 are presented in Table 1. While $M_{\text {total }}$ was $1.0\left(\mathrm{mmol} \mathrm{m}^{-2} \mathrm{yr}^{-1}\right)$ in 2003, it increased to 6.4 in 2004 and to 7.0 in 2005. In accordance with the increase in $M_{\text {total }}, M_{\text {atm }}$ also increased from $0.13 \pm 0.04\left(\mathrm{mmol} \mathrm{m}^{-2} \mathrm{yr}^{-1}\right)$ in 2003 to 2.6 in 2004 and 2.1 in 2005. $M_{\text {re }}$ also increased from $0.88 \pm 0.04$ $\left(\mathrm{mmol} \mathrm{m}^{-2} \mathrm{yr}^{-1}\right)$ in 2003 to 3.7 in 2004 and 4.8 in 2005.

The observed increases in $M_{\mathrm{atm}}$ and $M_{\mathrm{re}}$ in accordance with the Sasa cutting in October 2003 suggest that Sasa is important to prevention of nitrogen leaching from soil and enhancement of biological consumption of $\mathrm{NO}_{3}^{-}$atm before being exported from forest ecosystems, especially when significant quantities of $\mathrm{NO}_{3}^{-}$atm were added to the forest floor 
Table 2. Annual deposition rate of atmospheric nitrate at the monitoring tower $\left(\mathrm{mmol} \mathrm{m}^{-2} \mathrm{yr}^{-1}\right)$.

\begin{tabular}{lrrrrr}
\hline & FY2008 & FY2009 & FY2010 & FY2011 & Average \\
\hline Wet deposition & 11.9 & 17.4 & 13.9 & 17.2 & $15.1 \pm 2.7$ \\
Dry deposition & 3.2 & 3.0 & 3.9 & 3.7 & $3.5 \pm 0.4$ \\
Total & 15.1 & 20.4 & 17.8 & 20.9 & $18.6 \pm 2.7$ \\
\hline
\end{tabular}

through the spring snowmelt. Although both $M_{\mathrm{atm}}$ and $M_{\mathrm{re}}$ increased in response to strip-cutting, the relative increase in $M_{\text {atm }}$ was much higher than the relative increase in $M_{\mathrm{re}}$. These results imply that the major impact of strip-cutting was on the biological consumption processes of $\mathrm{NO}_{3}^{-}$atm, rather than the production processes of $\mathrm{NO}_{3}^{-}$re in soils.

While the annual average $M_{\mathrm{atm}} / M_{\text {total }}$ ratio was less than $16 \%$ in 2003 (Table 1), it increased to $41 \%$ in 2004 in response to strip-cutting, then slightly decreased to $31 \%$ in 2005. The $M_{\mathrm{atm}} / M_{\text {total }}$ ratios after strip-cutting were much higher than those determined for normal natural discharges, such as 3.1-7.7\% in southern California (Michalski et al., 2004), $7.4 \pm 2.6 \%$ on Rishiri Island (Tsunogai et al., 2010), and $0-7 \%$ in the Yellow River (Liu et al., 2013), as well as that dissolved in soil solution of temperate forest in northern Michigan (9\% on average)(Costa et al., 2011) and that dissolved in an oligotrophic lake water column in Japan $(9.7 \pm 0.8 \%)$ (Tsunogai et al., 2011). As a result, we can easily differentiate the ratios observed after strip-cutting from other normal $M_{\mathrm{atm}} / M_{\text {total }}$ ratios in stream water using the $\Delta^{17} \mathrm{O}$ values of nitrate, indicating that they can serve as a useful and powerful tracer for quantification of artificial alternations in forested watersheds.

\subsection{Quantifying the effects of strip-cutting on atmospheric nitrate dynamics}

If biological consumption processes of $\mathrm{NO}_{3}^{-}$atm were fully destroyed in the watershed owing to strip-cutting, the annual export flux via stream water $\left(M_{\mathrm{atm}}\right)$ would be the same as that deposited throughout the catchment area. Therefore, we determined the annual deposition flux of $\mathrm{NO}_{3}^{-}$atm $\left(D_{\text {atm }}\right)$ at the monitoring tower of the CC-LaG project adjacent to the catchment area (Fig. 1) to compare $M_{\text {atm }}$ with $D_{\text {atm }}$. The data coverage of the obtained daily deposition rate was $94 \%$ in FY2008, 89\% in FY2009, $95 \%$ in FY2010, and $82 \%$ in FY2011. To complement the lacking data of the daily deposition rate, we first determined the average daily deposition rate for each year based only on the obtained data set and then estimated the annual deposition flux $\left(D_{\mathrm{atm}}\right)$ for each year assuming the same daily deposition rate with the average for those lacking data. The annual deposition flux of $\mathrm{NO}_{3}^{-}$atm $\left(D_{\text {atm }}\right)$ was nearly stable at around $18.6 \pm 2.7\left(\mathrm{mmol} \mathrm{m}^{-2} \mathrm{yr}^{-1}\right)$, and wet deposition $\left(15.1 \pm 2.7 \mathrm{mmol} \mathrm{m}^{-2} \mathrm{yr}^{-1}\right)$ accounted for $81 \pm 3 \%$ of the total $\mathrm{NO}_{3}^{-}$atm deposition (Table 2). The estimated wet de- position flux of $\mathrm{NO}_{3}^{-}$atm corresponds with the average wet deposition flux of $\mathrm{NO}_{3}^{-}$atm determined at nearby Rishiri island (Fig. 1) through the continuous monitoring since 2001 $\left(13.5 \pm 2.9 \mathrm{mmol} \mathrm{m}^{-2} \mathrm{yr}^{-1}\right)($ EANET, 2013), as well as that deposited in a background area in eastern Asia (EANET, 2013). Furthermore, the estimated $D_{\text {atm }}$ corresponds with the total deposition flux of $\mathrm{NO}_{3}^{-}$atm determined preliminary in the forested watershed prior to clear-cutting using a bucket sampler (19.5 mmol m $\mathrm{m}^{-2} \mathrm{yr}^{-1}$ in 2002; Fukuzawa et al., personal communication, 2014). We conclude that the estimated $D_{\text {atm }}$ represents the annual deposition flux of $\mathrm{NO}_{3}^{-}$atm in the watershed irrespective to the year of observation.

When compared with the $D_{\text {atm }}$ estimated in this study, the annual export flux of $\mathrm{NO}_{3}^{-}$atm via stream water $\left(M_{\mathrm{atm}}\right)$ corresponds to less than $1 \%$ in 2003, about $14 \%$ in 2004, and about $12 \%$ in 2005 . In our previous study on nearby Rishiri Island using $\Delta^{17} \mathrm{O}$ of nitrate as a tracer, we estimated that direct drainage accounts for $8.8 \pm 4.6 \%$ of $\mathrm{NO}_{3}^{-}$atm that has been deposited onto the island on average, and that the residual portion has undergone biological processing before being exported from the surface ecosystem based on comparison of the inflow (deposition of atmospheric nitrate) and outflow (atmospheric nitrate in groundwater) (Tsunogai et al., 2010). The present study revealed that the studied forest ecosystem removed $\mathrm{NO}_{3}^{-}$atm more effectively in 2003 than that on Rishiri Island, while the removal efficiency was worse than that of Rishiri Island in 2004 owing to strip-cutting.

Both surface vegetation and the related ecosystems in soils must play a significant role in the consumption of $\mathrm{NO}_{3}^{-}$atm (Nakagawa et al., 2013). The area in which Sasa was stripcut only accounted for $50 \%$ of the total watershed. Additionally, larch seedlings were immediately planted in the Sasa strip-cut line. Although the removal processes of $\mathrm{NO}_{3}^{-}$atm by plants and/or microbes in the forested soils were damaged by strip-cutting, the results of the present study demonstrated that the majority of these processes were still active, even after strip-cutting. These findings will be useful in future to develop strategies for both clear-cutting and strip-cutting in forested ecosystems without increasing nitrate elution from watersheds. 


\section{Summary and conclusions}

To quantify the biogeochemical effects of clear-cutting of trees and subsequent strip-cutting of the understory vegetation in a cool-temperate forested watershed, temporal variations in the origin of nitrate dissolved in stream water eluted from the watershed were determined by using the $\Delta^{17} \mathrm{O}$ values of nitrate as tracers, with special emphasis on changes in the fate of atmospheric nitrate that had been deposited into the watershed. When compared with the values prior to strip-cutting, the annual export of atmospheric nitrate and remineralized nitrate increased by more than 13-fold and fourfold, respectively. These findings indicate that the understory vegetation is important to the biological consumption of atmospheric nitrate, especially when significant quantities of nitrate were added to the forest floor through the spring snowmelt. Additionally, the major impact of strip-cutting was on the biological consumption processes of atmospheric nitrate, rather than the production processes of remineralized nitrate in soils. Nevertheless, the annual export flux of atmospheric nitrate corresponds to less than $14 \%$ of atmospheric nitrate deposited into the watershed. Although the removal processes of atmospheric nitrate in the forested soils were damaged by strip-cutting, the majority of these processes were still active after strip-cutting. This study clearly demonstrates that temporal variations in the $\Delta^{17} \mathrm{O}$ values of nitrate in stream water can be a powerful tracer for quantification of artificial alternations in forested watersheds. Moreover, additional measurements of the $\Delta^{17} \mathrm{O}$ values of nitrate together with $\delta^{15} \mathrm{~N}$ and $\delta^{18} \mathrm{O}$ enable correction of the contribution of atmospheric nitrate from the determined values and use of the corrected $\delta^{15} \mathrm{~N}$ and $\delta^{18} \mathrm{O}$ values for evaluation of the behavior of remineralized nitrate in soils.

Acknowledgements. We thank the two anonymous referees for their valuable comments and suggestions on an earlier version of this manuscript. Both the clear-cutting and subsequent strip-cutting experiments were conducted as part of a collaboration among Hokkaido University, the National Institute for Environmental Studies (NIES), and Hokkaido Electric Power Co. through the CC-LaG project. We thank the staff of the Teshio Experimental Forest for their long-term water sampling. Additionally, we are grateful to the members of the Biogeochemistry Group, Graduate School of Environmental Studies, Nagoya University, for their valuable support throughout this study. This work was supported by a grant-in-aid of Scientific Research from the Ministry of Education, Culture, Sports, Science and Technology of Japan under grant numbers 22651001, 23241001, 24651002, and 25121506.

Edited by: N. Ohte

\section{References}

Aleem, M. I. H., Hoch, G. E., and Varner, J. E.: Water as the source of oxidant and reductant in bacterial chemosynthesis, P. Natl. Acad. Sci. USA, 54, 869-873, 1965.

Alexander, B., Hastings, M. G., Allman, D. J., Dachs, J., Thornton, J. A., and Kunasek, S. A.: Quantifying atmospheric nitrate formation pathways based on a global model of the oxygen isotopic composition $\left(\Delta^{17} \mathrm{O}\right)$ of atmospheric nitrate, Atmos. Chem. Phys., 9, 5043-5056, doi:10.5194/acp-9-5043-2009, 2009.

Amberger, A. and Schmidt, H.-L.: Natürliche Isotopengehalte von Nitrat als Indikatoren für dessen Herkunft, Geochim. Cosmochim. Ac., 51, 2699-2705, 1987.

Andersson, K. K. and Hooper, A. B.: $\mathrm{O}_{2}$ and $\mathrm{H}_{2} \mathrm{O}$ are each the source of one $\mathrm{O}$ in $\mathrm{NO}_{2}^{-}$produced from $\mathrm{NH}_{3}$ by $\mathrm{Ni}-$ trosomonas: ${ }^{15} \mathrm{~N}-\mathrm{NMR}$ evidence, FEBS Lett., 164, 236-240, doi:10.1016/0014-5793(83)80292-0, 1983.

Aravena, R. and Robertson, W. D.: Use of multiple isotope tracers to evaluate denitrification in ground water: study of nitrate from a large-flux septic system plume, Groundwater, 36, 975982, doi:10.1111/j.1745-6584.1998.tb02104.x, 1998.

Barnes, R. and Raymond, P. A.: Land-use controls on sources and processing of nitrate in small watersheds: insights from dual isotopic analysis, Ecol. Appl., 20, 1961-1978, 2010.

Barnes, R., Raymond, P., and Casciotti, K.: Dual isotope analyses indicate efficient processing of atmospheric nitrate by forested watersheds in the northeastern US, Biogeochemistry, 90, 15-27, 2008.

Böhlke, J. K., Mroczkowski, S. J., and Coplen, T. B.: Oxygen isotopes in nitrate: new reference materials for ${ }^{18} \mathrm{O}:{ }^{17} \mathrm{O}:{ }^{16} \mathrm{O}$ measurements and observations on nitrate-water equilibration, Rapid Commun. Mass Sp., 17, 1835-1846, 2003.

Breuer, L., Kiese, R., and Butterbach-Bahl, K.: Temperature and moisture effects on nitrification rates in tropical rain-forest soils, Soil Sci. Soc. Am. J., 66, 834-844, 2002.

Buchwald, C., Santoro, A. E., McIlvin, M. R., and Casciotti, K. L.: Oxygen isotopic composition of nitrate and nitrite produced by nitrifying cocultures and natural marine assemblages, Limnol. Oceanogr., 57, 1361-1375, doi:10.4319/lo.2012.57.5.1361, 2012.

Burns, D. A. and Kendall, C.: Analysis of $\delta^{15} \mathrm{~N}$ and $\delta^{18} \mathrm{O}$ to differentiate $\mathrm{NO}_{3}^{-}$sources in runoff at two watersheds in the Catskill Mountains of New York, Water Resour. Res., 38, 1051, doi:10.1029/2001wr000292, 2002.

Burns, D. A., Boyer, E. W., Elliott, E. M., and Kendall, C.: Sources and transformations of nitrate from streams draining varying land uses: evidence from dual isotope analysis, J. Environ. Qual., 38, 1149-1159, doi:10.2134/jeq2008.0371, 2009.

Campbell, D. H., Kendall, C., Chang, C. C. Y., Silva, S. R., and Tonnessen, K. A.: Pathways for nitrate release from an alpine watershed: determination using $\delta^{15} \mathrm{~N}$ and $\delta^{18} \mathrm{O}$, Water Resour. Res., 38, 1052, doi:10.1029/2001WR000294, 2002.

Casciotti, K. L., Böhlke, J. K., McIlvin, M. R., Mroczkowski, S. J., and Hannon, J. E.: Oxygen isotopes in nitrite: analysis, calibration, and equilibration, Anal. Chem., 79, 2427-2436, doi:10.1021/ac061598h, 2007.

Costa, A. W., Michalski, G., Schauer, A. J., Alexander, B., Steig, E. J., and Shepson, P. B.: Analysis of atmospheric inputs of nitrate to a temperate forest ecosystem from $\Delta^{17} \mathrm{O}$ 
isotope ratio measurements, Geophys. Res. Lett., 38, L15805, doi:10.1029/2011GL047539, 2011.

Curtis, C. J., Evans, C. D., Goodale, C. L., and Heaton, T. H. E.: What have stable isotope studies revealed about the nature and mechanisms of $\mathrm{N}$ saturation and nitrate leaching from semi-natural catchments?, Ecosystems, 14, 1021-1037, doi:10.1007/s10021-011-9461-7, 2011.

Dejwakh, N. R., Meixner, T., Michalski, G., and McIntosh, J.: Using ${ }^{17} \mathrm{O}$ to investigate nitrate sources and sinks in a semiarid groundwater system, Environ. Sci. Technol., 46, 745-751, doi:10.1021/es203450z, 2012.

Durka, W., Schulze, E.-D., Gebauer, G., and Voerkeliust, S.: Effects of forest decline on uptake and leaching of deposited nitrate determined from ${ }^{15} \mathrm{~N}$ and ${ }^{18} \mathrm{O}$ measurements, Nature, 372, 765767, 1994.

EANET: Data Report 2011, Network center for EANET (Acid Deposition Monitoring Network in East Asia), Nigata, Japan, 324 pp., 2013.

Fukuzawa, K., Shibata, H., Takagi, K., Nomura, M., Kurima, N., Fukazawa, T., Satoh, F., and Sasa, K.: Effects of clear-cutting on nitrogen leaching and fine root dynamics in a cool-temperate forested watershed in northern Japan, Forest Ecol. Manag., 225, 257-261, 2006.

Granger, J., Sigman, D. M., Lehmann, M. F., and Tortell, P. D.: Nitrogen and oxygen isotope fractionation during dissimilatory nitrate reduction by denitrifying bacteria, Limnol. Oceanogr., 53, 2533-2545, 2008.

Grennfelt, P. and Hultberg, H.: Effects of nitrogen deposition on the acidification of terrestrial and aquatic ecosystems, Water Air Soil Poll., 30, 945-963, 1986.

Hales, H. C., Ross, D. S., and Lini, A.: Isotopic signature of nitrate in two contrasting watersheds of Brush Brook, Vermont, USA, Biogeochemistry, 84, 51-66, doi:10.1007/S10533-007-9074-6, 2007.

Hirota, A., Tsunogai, U., Komatsu, D. D., and Nakagawa, F.: Simultaneous determination of $\delta^{15} \mathrm{~N}$ and $\delta^{18} \mathrm{O}$ of $\mathrm{N}_{2} \mathrm{O}$ and $\delta^{13} \mathrm{C}$ of $\mathrm{CH}_{4}$ in nanomolar quantities from a single water sample, Rapid Commun. Mass Sp., 24, 1085-1092, doi:10.1002/Rcm.4483, 2010.

Högberg, P.: Tansley Review No. $95^{15} \mathrm{~N}$ natural abundance in soilplant systems, New Phytol., 137, 179-203, 1997.

Hoyle, F. C., Murphy, D. V., and Fillery, I. R. P.: Temperature and stubble management influence microbial $\mathrm{CO}_{2}-\mathrm{C}$ evolution and gross $\mathrm{N}$ transformation rates, Soil Biol. Biochem., 38, 71-80, 2006.

Kaiser, J., Hastings, M. G., Houlton, B. Z., Röckmann, T., and Sigman, D. M.: Triple oxygen isotope analysis of nitrate using the denitrifier method and thermal decomposition of $\mathrm{N}_{2} \mathrm{O}$, Anal. Chem., 79, 599-607, doi:10.1021/ac061022s, 2007.

Kendall, C.: Tracing nitrogen sources and cycling in catchments, in: Isotope Tracers in Catchment Hydrology, edited by: Kendall, C., and McDonnell, J. J., Elsevier Science B. V., Amsterdam, 519576, 1998.

Kendall, C., Campbell, D. H., Burns, D. A., Schanley, J. B., Silva, S. R., and Chang, C. C. Y.: Tracing sources of nitrate in snowmelt runoff using the oxygen and nitrogen isotopic compositions of nitrate, in: Biogeochemistry of seasonally snow-covered catchments, Proceedings of a Boulder Symposium, IAHS Publication, 339-347, 1995.
Komatsu, D. D., Ishimura, T., Nakagawa, F., and Tsunogai, U.: Determination of the ${ }^{15} \mathrm{~N} /{ }^{14} \mathrm{~N},{ }^{17} \mathrm{O} /{ }^{16} \mathrm{O}$, and ${ }^{18} \mathrm{O} /{ }^{16} \mathrm{O}$ ratios of nitrous oxide by using continuous-flow isotope-ratio mass spectrometry, Rapid Commun. Mass Sp., 22, 1587-1596, doi:10.1002/rcm.3493, 2008.

Konno, U., Tsunogai, U., Komatsu, D. D., Daita, S., Nakagawa, F., Tsuda, A., Matsui, T., Eum, Y.-J., and Suzuki, K.: Determination of total $\mathrm{N}_{2}$ fixation rates in the ocean taking into account both the particulate and filtrate fractions, Biogeosciences, 7, 2369-2377, doi:10.5194/bg-7-2369-2010, 2010.

Kumar, S., Nicholas, D. J. D., and Williams, E. H.: Definitive ${ }^{15} \mathrm{~N}$ NMR evidence that water serves as a source of "O" during nitrite oxidation by nitrobacter agilis, FEBS Lett., 152, 71-74, 1983.

Likens, G. E., Bormann, F. H., Johnson, N. M., Fisher, D. W., and Pierce, R. S.: Effects of forest cutting and herbicide treatment on nutrient budgets in the Hubbard Brook watershed-ecosystem, Ecol. Monogr., 40, 23-47, 1970.

Liu, T., Wang, F., Michalski, G., Xia, X., and Liu, S.: Using ${ }^{15} \mathrm{~N},{ }^{17} \mathrm{O}$, and ${ }^{18} \mathrm{O}$ to determine nitrate sources in the Yellow River, China, Environ. Sci. Technol., 47, 13412-13421, doi:10.1021/es403357m, 2013.

Lohse, K. A., Sanderman, J., and Amundson, R.: Identifying sources and processes influencing nitrogen export to a small stream using dual isotopes of nitrate, Water Resour. Res., 49, 5715-5731, doi:10.1002/wrcr.20439, 2013.

Luz, B. and Barkan, E.: Assessment of oceanic productivity with the triple-isotope composition of dissolved oxygen, Science, 288, 2028-2031, doi:10.1126/science.288.5473.2028, 2000.

McCabe, J. R., Thiemens, M. H., and Savarino, J.: A record of ozone variability in South Pole Antarctic snow: role of nitrate oxygen isotopes, J. Geophys. Res., 112, D12303, doi:10.1029/2006jd007822, 2007.

McIlvin, M. R. and Altabet, M. A.: Chemical conversion of nitrate and nitrite to nitrous oxide for nitrogen and oxygen isotope analysis in freshwater and seawater, Anal. Chem., 77, 5589-5595, doi:10.1021/ac050528s, 2005.

Michalski, G., Savarino, J., Böhlke, J. K., and Thiemens, M.: Determination of the total oxygen isotopic composition of nitrate and the calibration of a $\Delta^{17} \mathrm{O}$ nitrate reference material, Anal. Chem., 74, 4989-4993, doi:10.1021/Ac0256282, 2002.

Michalski, G., Scott, Z., Kabiling, M., and Thiemens, M. H.: First measurements and modeling of $\Delta^{17} \mathrm{O}$ in atmospheric nitrate, Geophys. Res. Lett., 30, 1870, doi:10.1029/2003GL017015, 2003.

Michalski, G., Meixner, T., Fenn, M., Hernandez, L., Sirulnik, A., Allen, E., and Thiemens, M.: Tracing atmospheric nitrate deposition in a complex semiarid ecosystem using $\Delta^{17} \mathrm{O}$, Environ. Sci. Technol., 38, 2175-2181, 2004.

Miller, M. F.: Isotopic fractionation and the quantification of ${ }^{17} \mathrm{O}$ anomalies in the oxygen three-isotope system: an appraisal and geochemical significance, Geochim. Cosmochim. Ac., 66, 18811889, 2002.

Mizota, C. and Kusakabe, M.: Spatial distribution of $\delta \mathrm{D}-\delta^{18} \mathrm{O}$ values of surface and shallow groundwaters from Japan, south Korea and east China, Geochem. J., 28, 387-410, 1994.

Morin, S., Savarino, J., Frey, M. M., Yan, N., Bekki, S., Bottenheim, J. W., and Martins, J. M. F.: Tracing the origin and fate of $\mathrm{NO}_{\mathrm{X}}$ in the Arctic atmosphere using stable isotopes in nitrate, Science, 322, 730-732, doi:10.1126/science.1161910, 2008. 
Morin, S., Savarino, J., Frey, M. M., Domine, F., Jacobi, H. W., Kaleschke, L., and Martins, J. M. F.: Comprehensive isotopic composition of atmospheric nitrate in the Atlantic Ocean boundary layer from $65^{\circ} \mathrm{S}$ to $79^{\circ} \mathrm{N}$, J. Geophys. Res., 114, D05303, doi:10.1029/2008jd010696, 2009.

Nakagawa, F., Tsunogai, U., Gamo, T., and Yoshida, N.: Stable isotopic compositions and fractionations of carbon monoxide at coastal and open ocean stations in the Pacific, J. Geophys. Res., 109, C06016, doi:10.1029/2001JC001108, 2004.

Nakagawa, F., Suzuki, A., Daita, S., Ohyama, T., Komatsu, D. D., and Tsunogai, U.: Tracing atmospheric nitrate in groundwater using triple oxygen isotopes: evaluation based on bottled drinking water, Biogeosciences, 10, 3547-3558, doi:10.5194/bg-10-35472013, 2013.

Nestler, A., Berglund, M., Accoe, F., Duta, S., Xue, D., Boeckx, P., and Taylor, P.: Isotopes for improved management of nitrate pollution in aqueous resources: review of surface water field studies, Environ. Sci. Pollut. Res., 18, 519-533, doi:10.1007/s11356010-0422-z, 2011.

Noguchi, I., Hayashi, K., Aikawa, M., Ohizumi, T., Minami, Y., Kitamura, M., Takahashi, A., Tanimoto, H., Matsuda, K., and Hara, H.: Temporal trend of non-sea salt sulfate and nitrate in wet deposition in Japan, Water Air and Soil Poll., 7, 67-75, 2007a.

Noguchi, I., Otsuka, H., Akiyama, M., Sakai, S., and Kato, T.: Measuring concentrations of nitrous acid gas by the filter-pack sampling method, J. Japan Soc. Atmos. Environ., 42, 162-174, 2007b (in Japanese with English abstract).

Noguchi, I., Yamaguchi, T., Kawamura, M., Matsumoto, R., and Matsuda, K.: Updated program file for dry deposition velocity estimation based on the inferential method (Ver.4.1), Report of Institute of Environmental Sciences, 1, 21-31, 2011 (in Japanese).

Ohte, N., Sebestyen, S. D., Shanley, J. B., Doctor, D. H., Kendall, C., Wankel, S. D., and Boyer, E. W.: Tracing sources of nitrate in snowmelt runoff using a highresolution isotopic technique, Geophys. Res. Lett., 31, L21506, doi:10.1029/2004GL020908, 2004.

Ohte, N., Tayasu, I., Kohzu, A., Yoshimizu, C., Osaka, K., Makabe, A., Koba, K., Yoshida, N., and Nagata, T.: Spatial distribution of nitrate sources of rivers in the Lake Biwa watershed, Japan: controlling factors revealed by nitrogen and oxygen isotope values, Water Resour. Res., 46, W07505, doi:10.1029/2009wr007871, 2010.

Ohte, N.: Tracing sources and pathways of dissolved nitrate in forest and river ecosystems using high-resolution isotopic techniques: a review, Ecol. Res., 28, 749-757, 2013.

Pellerin, B., Saraceno, J., Shanley, J., Sebestyen, S., Aiken, G., Wollheim, W., and Bergamaschi, B.: Taking the pulse of snowmelt: in situ sensors reveal seasonal, event and diurnal patterns of nitrate and dissolved organic matter variability in an upland forest stream, Biogeochemistry, 108, 183-198, 2012.

Piatek, K. B., Mitchell, M. J., Silva, S. R., and Kendall, C.: Sources of nitrate in snowmelt discharge: evidence from water chemistry and stable isotopes of nitrate, Water Air Soil Poll., 165, 13-35, 2005.

Savarino, J., Kaiser, J., Morin, S., Sigman, D. M., and Thiemens, M. H.: Nitrogen and oxygen isotopic constraints on the origin of atmospheric nitrate in coastal Antarctica, Atmos. Chem. Phys., 7, 1925-1945, doi:10.5194/acp-7-1925-2007, 2007.
Spoelstra, J., Schiff, S. L., Hazlett, P. W., Jeffries, D. S., and Semkin, R. G.: The isotopic composition of nitrate produced from nitrification in a hardwood forest floor, Geochim. Cosmochim. Ac., 71, 3757-3771, doi:10.1016/J.Gca.2007.05.021, 2007.

Swank, W. T., Vose, J. M., and Elliott, K. J.: Long-term hydrologic and water quality responses following commercial clearcutting of mixed hardwoods on a southern Appalachian catchment, Forest Ecol. Manag., 143, 163-178, 2001

Takagi, K., Fukuzawa, K., Liang, N., Kayama, M., Nomura, M., Hojyo, H., Sugata, S., Shibata, H., Fukazawa, T., Takahashi, Y., Nakaji, T., Oguma, H., Mano, M., Akibayashi, Y., Murayama, T., Koike, T., Sasa, K., and Fujinuma, Y.: Change in $\mathrm{CO}_{2}$ balance under a series of forestry activities in a cool-temperate mixed forest with dense undergrowth, Glob. Change Biol., 15, 12751288, doi:10.1111/j.1365-2486.2008.01795.x, 2009.

Thibodeau, B., Hélie, J.-F., and Lehmann, M. F.: Variations of the nitrate isotopic composition in the St. Lawrence River caused by seasonal changes in atmospheric nitrogen inputs, Biogeochemistry, 115, 287-298, 2013.

Tietema, A., Emmett, B. A., Gundersen, P., Kjonaas, O. J., and Koopmans, C. J.: The fate of N-15-labelled nitrogen deposition in coniferous ecosystems, Forest Ecol. Manag., 101, 19-27, 1998.

Tobari, Y., Koba, K., Fukushima, K., Tokuchi, N., Ohte, N., Tateno, R., Toyoda, S., Yoshioka, T., and Yoshida, N.: Contribution of atmospheric nitrate to stream-water nitrate in Japanese coniferous forests revealed by the oxygen isotope ratio of nitrate, Rapid Commun. Mass Sp., 24, 1281-1286, doi:10.1002/rcm.4498, 2010.

Tsunogai, U., Yoshida, N., Ishibashi, J., and Gamo, T.: Carbon isotopic distribution of methane in deep-sea hydrothermal plume, Myojin Knoll Caldera, Izu-Bonin arc: implications for microbial methane oxidation in ocean and applications to heat flux estimation, Geochim. Cosmochim. Ac., 64, 2439-2452, doi:10.1016/S0016-7037(00)00374-4, 2000.

Tsunogai, U., Nakagawa, F., Komatsu, D. D., and Gamo, T.: Stable carbon and oxygen isotopic analysis of atmospheric carbon monoxide using continuous-flow isotope ratio MS by isotope monitoring of $\mathrm{CO}$, Anal. Chem., 74, 5695-5700, doi:10.1021/ac020290x, 2002.

Tsunogai, U., Nakagawa, F., Gamo, T., and Ishibashi, J.: Stable isotopic compositions of methane and carbon monoxide in the Suiyo hydrothermal plume, Izu-Bonin arc: tracers for microbial consumption/production, Earth Planet. Sci. Lett., 237, 326-340, doi:10.1016/j.epsl.2005.05.042, 2005.

Tsunogai, U., Kido, T., Hirota, A., Ohkubo, S. B., Komatsu, D. D., and Nakagawa, F.: Sensitive determinations of stable nitrogen isotopic composition of organic nitrogen through chemical conversion into $\mathrm{N}_{2} \mathrm{O}$, Rapid Commun. Mass Sp., 22, 345-354, doi:10.1002/rcm.3368, 2008.

Tsunogai, U., Komatsu, D. D., Daita, S., Kazemi, G. A., Nakagawa, F., Noguchi, I., and Zhang, J.: Tracing the fate of atmospheric nitrate deposited onto a forest ecosystem in eastern Asia using $\Delta^{17} \mathrm{O}$, Atmos. Chem. Phys., 10, doi:10.5194/acp-10-18092010, 1809-1820, 2010.

Tsunogai, U., Daita, S., Komatsu, D. D., Nakagawa, F., and Tanaka, A.: Quantifying nitrate dynamics in an oligotrophic 
lake using $\Delta^{17} \mathrm{O}$, Biogeosciences, 8, 687-702, doi:10.5194/bg8-687-2011, 2011.

Vitousek, P. M. and Melillo, J. M.: Nitrate losses from disturbed forests: patterns and mechanisms, Forensic Science, 25, 605619, 1979.

Wada, E., Kadonaga, T., and Matsuo, S.: ${ }^{15} \mathrm{~N}$ abundance in nitrogen of naturally occurring substances and global assessment of denitrification from isotopic viewpoint, Geochem. J., 9, 139-148, 1975.

Williams, M. W., Baron, J. S., Caine, N., Sommerfeld, R., and Sanford, R.: Nitrogen Saturation in the Rocky Mountains, Environ. Sci. Technol., 30, 640-646, 1996.

Williard, K. W. J., DeWalle, D. R., Edwards, P. J., and Sharpe, W. E.: ${ }^{18} \mathrm{O}$ isotopic separation of stream nitrate sources in mid-Appalachian forested watersheds, J. Hydrol., 252, 174$188,2001$.
Yamazaki, A., Watanabe, T., and Tsunogai, U.: Nitrogen isotopes of organic nitrogen in reef coral skeletons as a proxy of tropical nutrient dynamics, Geophys. Res. Lett., 38, L19605, doi:10.1029/2011GL049053, 2011.

Yue, F.-J., Li, S.-L., Zhao, Z.-Q., and Hu, J.: Using dual isotopes to evaluate sources and transformation of nitrogen in the Liao River, northeast China, Appl. Geochem., 36, 1-9, doi:10.1016/j.apgeochem.2013.06.009, 2013.

Zaman, M. and Chang, S. X.: Substrate type, temperature, and moisture content affect gross and net $\mathrm{N}$ mineralization and nitrification rates in agroforestry systems, Biol. Fertil. Soils, 39, 269279, 2004. 